\title{
United Kingdom: Report on the Observance of Standards and Codes
}

This paper was prepared based on the information available at the time it was completed on July 11, 2011. The views expressed in this document are those of the staff team and do not necessarily reflect the views of the government of the United Kingdom or the Executive Board of the IMF.

The policy of publication of staff reports and other documents by the IMF allows for the deletion of market-sensitive information.

Copies of this report are available to the public from

International Monetary Fund • Publication Services 700 19th Street, N.W. • Washington, D.C. 20431

Telephone: (202) 623-7430 • Telefax: (202) 623-7201

E-mail: publications@imf.org •Internet: http://www.imf.org

\section{International Monetary Fund Washington, D.C.}


FINANCIAL SECTOR ASSESSMENT PROGRAM UPDATE

\section{UNITED KINGDOM}

\section{REPORT ON THE OBSERVANCE OF STANDARDS AND CODES (ROSCS) - SUMMARY ASSESSMENTS}

JULY 2011 
Glossary

I. Basel Core Principles for Effective Banking Supervision.......................................6

A. Summary, Key Findings, and Recommendations .................................................6

B. Recommended Action Plan and Authorities' Response ........................................19

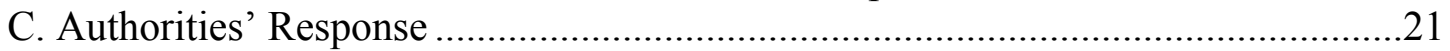

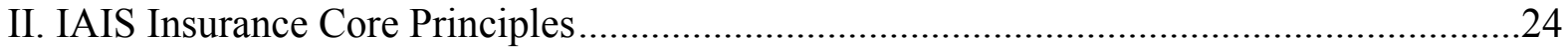

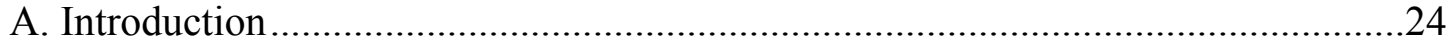

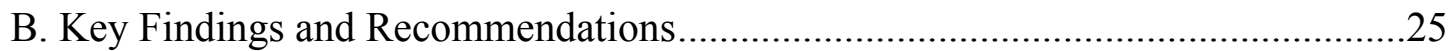

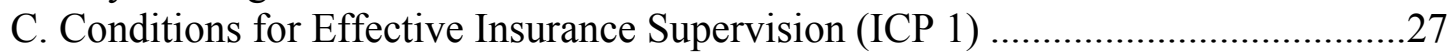

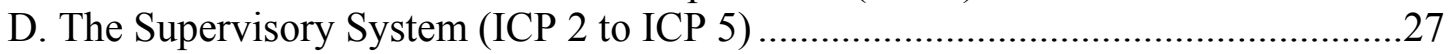

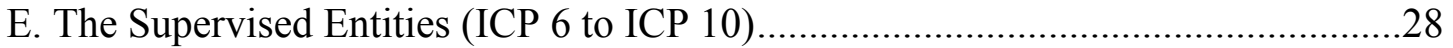

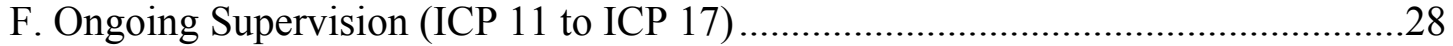

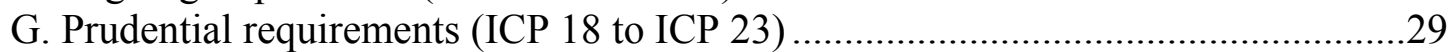

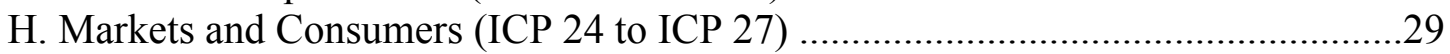

I. Anti-Money Laundering/Combating the Financing of Terrorism (ICP 28) .............29

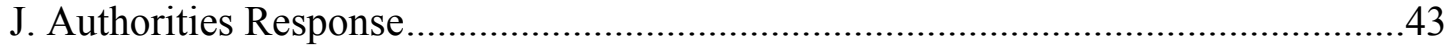

III. IOSCO Objectives and Principles of Securities Regulation .........................................44

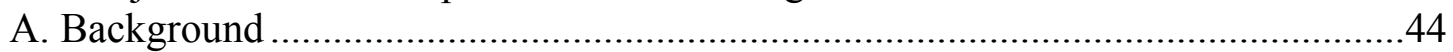

B. Financial Services Authority Approach to Supervision ........................................45

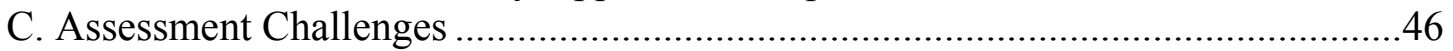

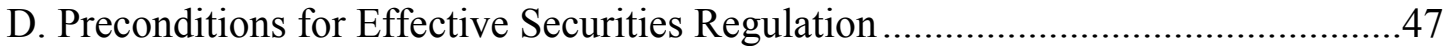

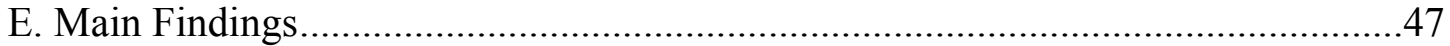

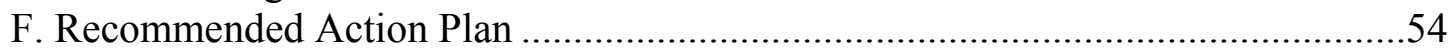

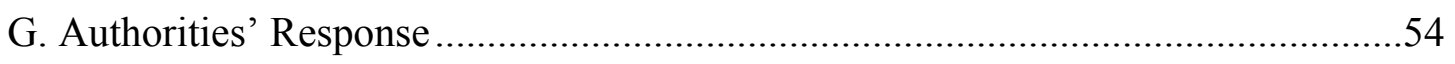

IV. CPSS Core Principles for Systemically Important Payment Systems - CHAPS .............55

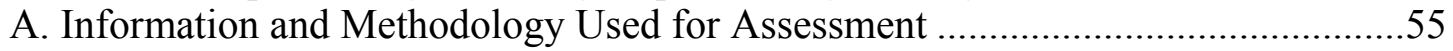

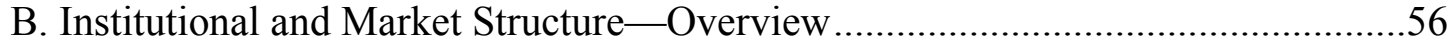

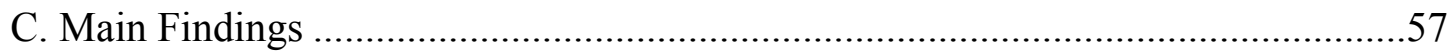

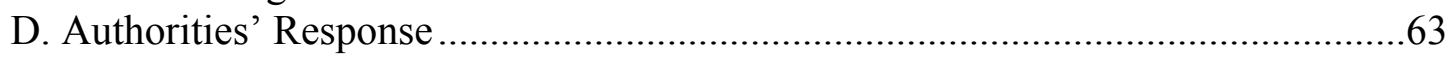

V. CPSS/IOSCO Recommendations for Securities Settlement Systems - CREST ..............63

A. Information and Methodology Used for Assessment ......................................63

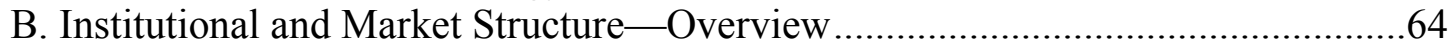

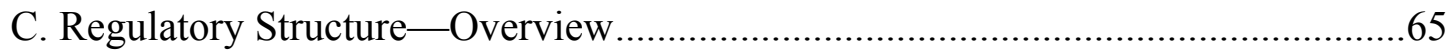

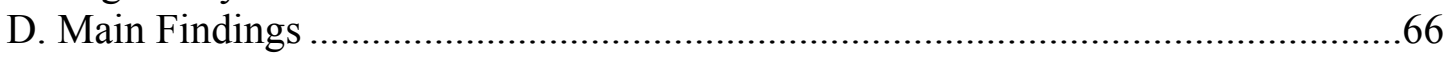

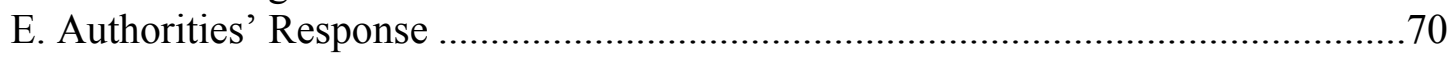

VI. CPSS/IOSCO Recommendations for Central Counterparties-LCH.Clearnet Limited ...70

A. Information and Methodology Used for Assessment ….................................... 70

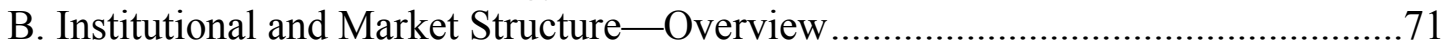

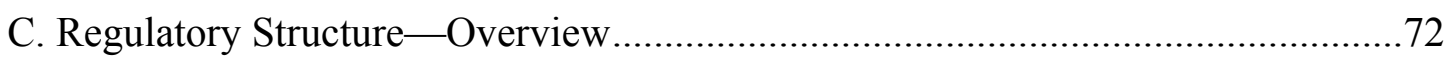




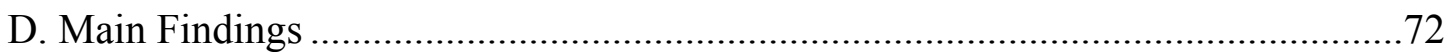

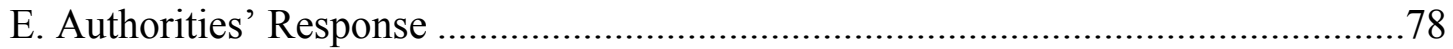

Tables

1. Summary Compliance with the Basel Core Principles-ROSCs ..........................................14

2. Recommended Action Plan to Improve Compliance with the Basel Core Principles.........19

3. Summary of Observance of the Insurance Core Principles-Detailed Assessments ..........29

4. Recommended Action Plan to Improve Observance of the Insurance Core Principles .......41

5. Summary Implementation of the IOSCO Principles-Detailed Assessments ......................50

6. Recommended Action Plan to Improve Implementation of the IOSCO Principles .............54

7. Statistical Information Regarding CHAPS .......................................................................56

8. Recommended Action Plan to Improve Observance of the CPSIPS and Central Bank

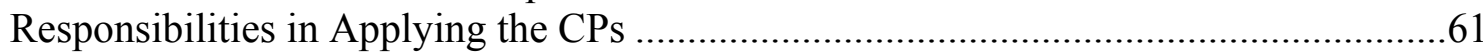

9. Additional Recommendations to Go Beyond Observance of the CPSIPS and Central Bank

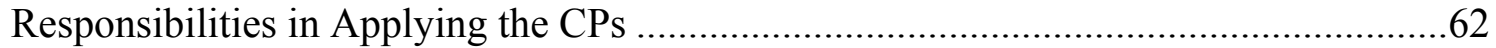

10. Recommended Action Plan to Improve Observance ...................................................69

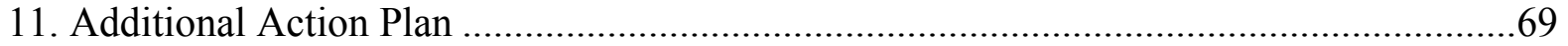

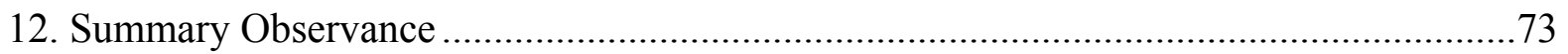

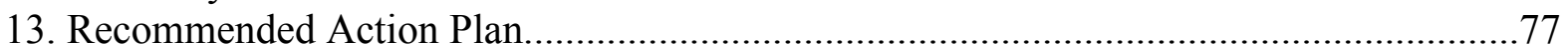

Figure

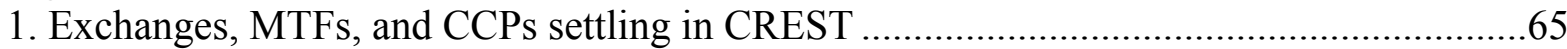




\section{GLOSSARY}

\begin{tabular}{|c|c|}
\hline $\mathrm{ABI}$ & Association of British Insurers \\
\hline $\mathrm{AML} / \mathrm{CFT}$ & Anti-Money Laundering/Combating the Financing of Terrorism \\
\hline ARROW & Advanced, Risk Responsive Operating FrameWork \\
\hline $\mathrm{BCP}$ & Basel Core Principles for Effective Banking Supervision \\
\hline Basel Committee & Basel Committee on Banking Supervisors \\
\hline BoE & Bank of England \\
\hline $\mathrm{CCP}$ & Central counterparty \\
\hline $\mathrm{CDS}$ & Credit default swaps \\
\hline CESR & Committee of European Securities Regulators \\
\hline CHAPS & Clearing House Automated Payment System \\
\hline $\mathrm{CP}$ & Core principles \\
\hline CPPI & Core Prudential Program for Insurers \\
\hline CRD & Capital Resources Directive \\
\hline CSD & Central Securities Depository \\
\hline EEA & European Economic Area \\
\hline ERM & Enterprise risk management \\
\hline ETFS & Exchange-traded funds \\
\hline EU & European Union \\
\hline EUI & Euroclear U.K. \& Ireland Limited \\
\hline FCA & Financial Conduct Authority \\
\hline FCD & Financial conglomerates directive \\
\hline FPS & Faster Payment Service \\
\hline FRR & Financial risk reviews \\
\hline FSA & Financial Services Authority \\
\hline FSAP & Financial Sector Assessment Program \\
\hline FSMA & Financial Services Market Act \\
\hline GAAP & Generally Accepted Accounting Principles \\
\hline HMT & Her Majesty’s Treasury \\
\hline IAIS & International Association of Insurance Supervisors \\
\hline $\mathrm{ICA}$ & Internal capital assessment \\
\hline ICAS & Individual capital adequacy structures \\
\hline ICPs & Insurance Core Principles \\
\hline ICSD & International Central Securities Depository \\
\hline IFRS & International Financial Reporting Standards \\
\hline IGD & European Insurance Group Directive \\
\hline IOSCO & International Organization of Securities Commission \\
\hline IRRBB & Interest Rate Risk in the Banking Book \\
\hline $\mathrm{LCH}$ & LCH Clearnet Limited \\
\hline LSE & London Stock Exchange \\
\hline MiFID & Markets in Financial Instruments Directive \\
\hline MOU & Memorandum of understanding \\
\hline MMOU & Multilateral memorandum of understanding \\
\hline MTFS & Multilateral Trading Facilities \\
\hline PRA & Prudential Regulation Authority \\
\hline
\end{tabular}


RCCP

RSSS

RTGS

UCITS

U.K.

UKLA
Recommendations for Central Counterparties

Recommendation for Securities Settlement System

Real time gross settlement

Undertaking for the Collective Investment of Transferable Securities

United Kingdom

United Kingdom Listing Authority 


\section{Basel Core Principles for Effective Banking SuPERVision}

\section{A. Summary, Key Findings, and Recommendations}

1. Although the United Kingdom (U.K.) has a high level of compliance with the Basel Core Principles for Effective Banking Supervision (BCP), the financial crisis has necessitated several important changes. As in other countries, the crisis revealed serious deficiencies in risk measurement and risk management at major banks, as well as weaknesses in supervisors' ability to identify deficiencies and have these rectified. The correct response has been put in place, and effective implementation of the already planned work program is now needed to achieve full compliance with the Principles, but the process is still at an early stage. In addition, major changes in the organization of and the new mandates for micro- and macro-prudential regulation and supervision risk introducing uncertainty. These changes have the potential to add to effectiveness, but given the newness of some of these concepts, expectations should be kept at a reasonable level and these new developments should not detract from the high standards required for core supervision. The U.K. authorities are strongly committed to both the supervisory reform programs and the cultural change necessary to implement these changes. Senior management of the Financial Services Authority (FSA) will need to maintain an ongoing focus on these issues in order to implement the core programs at the same time as new initiatives, related to the addition of a macro-prudential overlay in a new organizational structure, are developed.

\section{Introduction}

2. This assessment of the current state of the U.K. compliance with the BCP has been completed as part of a Financial Sector Assessment Program (FSAP) undertaken by the IMF during January-March 2011. ${ }^{1}$ It reflects the regulatory and supervisory framework in place as of the date of the completion of the assessment. The standards were evaluated in the context of the U.K. financial system's sophistication and complexity. As such, given London's role as one of the two most important global financial centers, the expectations applied in evaluating U.K. compliance were high. These factors should be taken into account when comparing the U.K. assessment with that of other countries. Importantly, this assessment is not intended to assess the merits of the wide-ranging program of structural reforms currently being proposed by the U.K. authorities.

\section{Information and methodology used for assessment}

3. The U.K. authorities agreed to be assessed according to the BCP Methodology issued by the Basel Committee on Banking Supervision (Basel Committee) in

\footnotetext{
${ }^{1}$ The BCP assessment team comprised Nick Le Pan, formerly of OSFI Canada, Antonio Pancorbo, Bank of Spain, and Pierre-Yves Thoraval, Promontory Group.
} 
October 2006. This methodology has a heightened focus on bank risk management and its assessment by the supervisory authority. The assessment of compliance with each Core Principle (CP) is made on a qualitative basis to allow a judgment on whether the criteria are fulfilled in practice. Reaching conclusions required judgments by the assessment team. Banking systems differ from one country to another, as do their domestic circumstances. Furthermore, banking activities are changing rapidly around the world after the crisis, and theories, policies, and best practices for supervision are swiftly evolving.

4. The assessment team reviewed the framework of laws, rules, and guidance, and held extensive meetings with officials of the FSA, the Bank of England (BoE), Her Majesty's Treasury (HMT), and private sector participants. They also met industry associations representing banks, rating agencies, audit firms, and private sector participants in banking and financial markets. The team examined the FSA's current practices in performing bank supervision. It had the benefit of working with a very comprehensive, highquality self-assessment completed by the authorities. It also enjoyed the high-quality cooperation of the authorities, and received the information it required. The team extends its thanks to the authorities' staff for their excellent cooperation at a time when many initiatives related to domestic and global financial stability were in progress.

\section{Institutional and macroeconomic setting and market structure-overview ${ }^{2}$}

\section{The U.K. supervisory authorities, since the creation of the FSA in 1998, have operated a 'tripartite' system involving the BoE, HMT and the FSA. Their various} responsibilities were set out in a public memorandum of understanding (MOU). The FSA has been responsible for prudential regulation and supervision of authorized financial institutions, markets, and consumer protection. At the time of the assessment, it regulated about 16,000 institutions, including 235 deposit-taking organizations (banks and building societies). The tripartite role for the BoE prior to 2009 related to the oversight of payment systems, maintaining a broad view of the system as a whole, and acting as a lender-of-lastresort. Since then, amendments to the Banking Act have given the BoE resolution authority over banks. HMT has been responsible for the institutional structure of regulation and legislation, accounting to parliament for the management of serious problems in the financial sector and authorization of support operations beyond the normal framework. In 2010, the new government proposed major changes to the tripartite system and the formal implementation of a macro-prudential overlay on traditional micro-prudential regulation and supervision. Prior to the crisis, the FSA had been operating what came to be known as a principles-based, risk-based regulatory approach, following a deregulation philosophy that was widely supported. In hindsight, the crisis demonstrated that supervisors had placed too much confidence in banks' internal risk management and governance systems.

\footnotetext{
${ }^{2}$ Further elaborations on the U.K. general macroeconomic background can be found in the Financial Sector Stability Assessment Report.
} 
6. The U.K. financial sector is large, with bank balance sheets amounting to approximately five times GDP. Other important sectors include asset management, insurance, and pension plans. Some of the most important asset managers are associated with banks, and the United Kingdom allows bancassurance. Leading U.K. banks are among the most complex internationally and London is a premier financial center. The crisis has materially affected the structure of the U.K. banking sector. U.K. banks faced losses from structured products and off-balance sheet vehicles to a degree, but also from asset quality problems in mortgages and business lending, as a result of previous high growth coupled with over-reliance in some cases on short-term wholesale funding. A number of mediumsized banks and building societies 'failed' during the crisis, and two large banks required material injections of public money. Concentration in the banking sector has increased. Certain banks and building societies had strategic concentrations that led to asset quality problems, such as concentrations in commercial real estate. Mergers of banks were already occurring prior to the crisis, and subsequent mergers occurred as part of the resolution of specific problems. The five largest banks, including the largest building society, and the largest foreign bank together account for close to 90 percent of retail deposits.

7. The U.K. banking system is facing a number of risks. Household indebtedness is high and could be affected adversely by future increases in interest rates or an economic slowdown. There are downside risks to asset quality, though the level of new impairments has trended down over the past year. The government has introduced an austerity program, and the impact on short-term growth is uncertain. The banking system has significant exposures to commercial real estate and material indirect exposure to vulnerable Euro-zone economies. There are substantial wholesale funding maturities that major U.K. banks will be facing over the coming years, though the FSA reported they all have plans to manage that risk. In terms of mitigation, aggregated Tier 1 capital has risen and compares favorably to other major international banking systems. Actions by the authorities, market pressures, and experience from the crisis have led to banks having enhanced short-term liquidity.

\section{Preconditions for effective banking supervision}

8. In terms of sound and sustainable macroeconomic policies, the U.K. economy has been slowly recovering from the crisis, but future economic growth remains uncertain. The central IMF projection for the United Kingdom indicates a progressive strengthening of private and external demand, which will underpin a moderate-paced recovery, even as the public sector retrenches. The BoE operates under a price-stability mandate. Inflation is currently well above the 2 percent target, but the central IMF projection forecasts a steady decline.

9. Overall, the public infrastructure supporting effective banking supervision in the United Kingdom is well developed. Business laws including contract, bankruptcy, and property law are well developed and reliable. There is an independent judiciary operating under a mixture of common law and statute law. Accounting, auditing, and legal professions 
are long established, well resourced, and well regulated. The International Financial Reporting Standards (IFRS) are used by U.K. listed companies. Nonlisted companies can use U.K. Generally Accepted Accounting Principles (GAAP), which is substantially harmonized with IFRS.

10. The foundations for effective market discipline are in place. There is a welldeveloped system of regular disclosure by public companies that supports market discipline. In addition, a key feature of the market in the United Kingdom is the extensive presence of institutional investors and high involvement of major rating agencies and analysts. For banks, disclosure is less than in other leading markets and the authorities should review its adequacy.

11. The U.K. framework for crisis management and safety nets has evolved rapidly since the start of the crisis. Significant gaps in the legal framework for bank resolution prompted an emergency legal response that was later enacted permanently in the 2009 Banking Act. This established a permanent regime for the resolution of distressed banks and building societies, and modified the arrangements for the liquidation and administration of insolvent institutions. The crisis also triggered (i) extraordinary BoE liquidity facilities and asset purchase programs; (ii) government guarantees over new issuances of short- and medium-term bank debt securities; (iii) public-funded bank recapitalization programs; and (iv) the extension of the guarantee on bank deposits.

\section{Main findings}

Objectives, independence, powers, transparency, and cooperation (CP 1)

\section{As an integrated regulator, the FSA has been able to gain a broad view of the} financial system, both of its safety and soundness and market conduct. However, the assessors have observed at many levels the impact of a lack of clarity about how the FSA intended to meet its very-generally-worded mandate. Prudential objectives were not explicitly mentioned in the statutory mandate and regulatory objectives. Also, certain other statutory qualifiers to the core regulatory objectives (such as the desirability of maintaining the United Kingdom's competitive position, and the need to minimize the impact of FSA actions on competition) may have been understood in ways that undercut adequate prudential supervision and regulation. 'Contributing to financial stability' was added to the regulatory objectives in 2010, and the FSA published its board-approved strategy to comply with the new regulatory objective and what that would mean in practice; however, it is too soon to observe the impact of this change. The way that regulatory objectives are to be expressed in the new structure was under discussion at the time of the assessment.

13. The FSA enjoys operational independence in its day-to-day decisions and sets its own budget needed to meet its regulatory objectives, however, additional resources are needed to enable the FSA to implement its planned enhancements without affecting the core work on prudential regulation and supervision. The Chairman of the FSA is 
appointed for a five-year term, but legislation allows for removal by HMT with no explicit grounds and no explicit requirement for public disclosure of the reasons for removal; however, this has never happened in practice. The FSA has materially increased its resources in the past two years to implement a more 'intensive and intrusive' supervisory process. Some of the newly launched processes are at an early stage, so it is difficult to assess steady state resource requirements. Assessors were not in a position to do a detailed analysis, but their strong sense is that additional resources for prudential regulation and supervision (a combination of enhanced skills and additional staff) are required, while recognizing that some of this could be funded from efficiencies in existing processes that the FSA is now assessing. Such additional resources are essential to enable the FSA to (i) implement the planned enhancements; (ii) deal with a number of recommendations in this assessment (such as for a more proactive detailed review of key risk areas); and (iii) implement the new macro overlay without drawing resources away from core prudential work. Other areas for enhancement include information reporting from banks, and the availability of more detailed data for effective peer analysis. Mechanisms are in place for information sharing and cooperation among the authorities.

\section{Licensing and structure (CPs 2-5)}

14. The FSA runs a comprehensive and effective licensing and approvals structure. A key part of their supervisory methodology is satisfying themselves that the overseers of authorized banks, and persons in positions of significant influence such as Board members and senior management, are 'fit and proper.' Assessors saw the comprehensive nature of that process and the importance the FSA places on it.

\section{Prudential regulation and requirements (CPs 6-18)}

15. The FSA has put considerable effort into enhancing the quality and quantity of capital in banks, and this is showing results. Capital rules are compliant with the Basel Committee and European requirements. The FSA has also built on its long tradition of setting individual capital targets, now capital guidance, for banks above the minimum. The robust stress testing process for major banks is instrumental in the FSA setting further capital buffers for major banks, above the normal FSA individual capital guidance.

\section{Severe shortcomings in certain bank risk measurement and risk management} practices were revealed in the crisis and supervisory oversight was not always effective in identifying those weaknesses and having them remedied. While it would have been unrealistic to expect a financial crisis of this magnitude not to reveal weaknesses, the extent and seriousness of them, particularly at some major U.K. banks, was remarkable, although not unique to the United Kingdom. Given the systemic importance of the United Kingdom, bank risk management practices, and the U.K. authorities' ability to assess them, must be held to a very high standard. Banks are undertaking major risk management and risk governance improvements, but these can be complex and time consuming to embed properly. FSA capabilities for liquidity risk assessment and effective intervention on liquidity issues 
are well advanced. This has involved updated guidance that in a number of ways pre-dated the recent global regulatory initiatives by the Basel Committee. The liquidity positions of major banks have improved as a result. For market risk and interest-rate risk in the banking book, assessors saw excellent examples of supervisory reviews. These have benefited from the FSA risk specialist resources. However, the assessors noted that there was room to increase the number of proactive deep-dive reviews and the amount of peer analysis based on improved reporting. Such enhancements would provide further assurance of the quality of market risk measurement, risk management, and risk governance. This issue is more of a deficiency in the FSA's overall supervisory approach, as discussed below, rather than a specific issue in the market risk area. Processes to relate capital to risk are more advanced.

\section{The FSA has responded with high-quality measures to enhance risk} measurement, management and governance, supervisory assessment and intervention. The assessors believe that the strategies are the correct ones. However, execution of the strategies is challenging in the current environment and completion of the enhancements is expected by the end of 2012. Sustained leadership is required to ensure continued implementation of these measures and to achieve judgment-based intensive supervision. The latter will include prompt intervention based on sufficient detailed supervisory work to identify and to deal with problems before they become serious.

18. The FSA needs to materially enhance its focus on credit risk at a more detailed level, with more, regular and proactive reviews of the quality of banks' portfolios. This will also involve more granular data from the banks operating credit risk models so that the FSA can perform assessments of the integrity of those processes and conduct effective peer analysis. The current detailed reviews need to be expanded, and resource constraints should be addressed to enable such priority work to be undertaken as soon as possible. Reviews should also consider the quality of banks' credit risk management, provisioning, and governance processes.

\section{Methods of ongoing banking supervision (CPs 19-21)}

19. The enhancement of the overall supervisory approach, which has already been started, needs to be continued with the same rigor, adequately embedded, and materially augmented to incorporate more detailed, in-depth reviews and proactive reviews. While the FSA has generally demonstrated its ability to use various supervisory techniques, the overall supervisory approach needs to (i) be enhanced to ensure coherence and cohesion; and (ii) continue to incorporate detailed supervisory reviews. In this context, it is critical to ensure that the new macro-prudential overlay will assist in the re-engineering process, and not divert resources from core supervision. The FSA recognizes the issues, and has responded with its new Core Prudential Program for very high-impact banks. But much of this will not be embedded for a number of years. Without more detailed verification, the assurance given by the current assessments of the quality of risk management and governance processes may not be adequate. The Advanced, Risk Responsive Operating 
FrameWork (ARROW) risk assessment process, which is at the core of the current methodology, is complex and does not seem to adequately discriminate among risks at major banks. There is also room to better integrate the results of reviews with risk rating and feedback to bank boards.

20. Senior FSA management recognized the need to improve the existing supervisory framework and has therefore committed much more time to oversight of the key risks in meeting the FSA regulatory objectives. Major issues and decisions are escalated by supervisory teams through a "watch list" process for consideration by the FSA Senior Executive team. This essentially amounts to a high-level judgmental overlay on the supervisory process. The FSA has also introduced a regular and direct contact program between the senior FSA management and the CEOs of the United Kingdom's largest banks. All major supervisory judgments are communicated both by its senior management team as well as the lead supervisors. The FSA believes that this approach has been broadly successful in identifying potential major issues in the recent past. However, it is not a sustainable substitute for the necessary enhancements and carries risks, as the FSA itself recognizes.

\section{Accounting and disclosure (CP 22)}

21. Banks' public disclosure can be improved in terms of comparability, relevance, scope, and timeliness. The FSA is open to considering disclosing nonconfidential prudential returns, such as the balance sheet and income statement, loans and investments, asset quality, funding structure, capital structure, and off-balance sheet exposures. To improve accounting and disclosure practices, the FSA has initiated more regular discussions with banks' auditors, including bilateral meetings with financial services audit partners for the largest audit firms. Recently, the FSA has begun to express a general desire that the audit profession should exercise more professional skepticism and that auditors should do more work in selected areas.

\section{Corrective and remedial powers of supervisors (CP 23)}

22. The FSA identifies problems in banks that require remedial action as part of the supervisory program, but could improve the linking of interventions to the seriousness of issues. The supervisory approach needs to strengthen the focus on important deficiencies. The supervisory approach is also still moving from a more-reactive to a more-proactive stance. The U.K. authorities would benefit from having a well articulated, judgment based, prompt intervention framework (not necessarily with pre-set triggers). The culture change will understandably take time and FSA management will need to maintain an ongoing focus on this issue.

23. The FSA has the necessary tools for corrective and remedial actions and the assessors saw evidence of their use in practice. These tools include (i) remedial action plans with banks as part of the supervisory process; (ii) the ability to set capital add-ons; (iii) formal power to impose conditions on a bank's authorization if it is not abiding by FSA 
rules; and (iv) the ability to levy fines. It is difficult for assessors to confirm (based on information presented by the FSA) that the desired proactive intervention is being applied clearly and consistently.

24. The FSA also has authority to declare a bank nonviable by determining that it is not meeting, or is likely not to meet, specified threshold conditions. These conditions include adequacy of resources. If that condition exists, and if it is determined that there is no immediate prospect that the bank could meet those conditions, the FSA can trigger the start of the special resolution process conducted by the BoE. This process, which is relatively new, has been used once in the resolution of a medium-sized building society. In putting in place a prompt intervention framework and in enhancing arrangements between the authorities, they should consider lessons learned from that experience.

\section{Consolidated and cross-border banking supervision (CPs 24-25)}

25. The United Kingdom applies consolidated supervision; however, the existing legislation for consolidated supervision needs to be strengthened. The authorities report that they get excellent cooperation from banks. However, the FSA has no legal power directly over the parent holding company of the banking group. So, formal remedial action, if necessary, has to be through the authorized banks in the group, which might not always be possible if the authorized banks are not sufficiently significant within the consolidated group. The alternative is for the FSA to use its powers to ring-fence the bank from the rest of the group, which may not be appropriate in all circumstances. As a result of the lack of power over parent holding companies, the FSA has no direct authority to approve the acquisition of banks or other financial firms by the parent holding company (it would have authority if the bank in the group was making the acquisition or if the target-entity was another FSAauthorized entity). This could be problematic if the target-entity is not a U.K. bank. At the time of the assessment, the U.K. government was seeking expert advice on extending FSA powers over unregulated holding companies.

\section{The FSA has an extensive network of MOUs and informal arrangements with} other home and host supervisors, as well as appropriate legal powers to share information and keep information confidential, as necessary. Given the openness of the U.K. market and the global reach of major U.K. banks, it is essential that these arrangements, and their enhancement through supervisory colleges, work well. The United Kingdom is also host to a number of major branches of EU banks. Under EU single-passport rules, these are not to be supervised by the host-country, except for liquidity. It is essential that home-host arrangements work well in these cases to ensure the effectiveness of both the home and host supervisors. The assessors discussed the practical arrangements with the FSA and suggested improvements in some cases.

27. Table 1 offers, principle-by-principle, a summary of assessment results: 
Table 1. Summary Compliance with the Basel Core Principles-ROSCs

\begin{tabular}{|c|c|}
\hline Core Principle & Comments \\
\hline \multicolumn{2}{|l|}{$\begin{array}{l}\text { 1. Objectives, independence, powers, } \\
\text { transparency, and cooperation }\end{array}$} \\
\hline 1.1 Responsibilities and objectives & $\begin{array}{l}\text { Statutory regulatory and supervisory } \\
\text { mandates are open to very considerable } \\
\text { ranges of interpretation and lack clarity with } \\
\text { respect to prudential objectives and how } \\
\text { these are to be interpreted vis-à-vis statutory } \\
\text { 'principles of good regulation,' such as } \\
\text { maintaining the competitiveness of the } \\
\text { United Kingdom and minimizing impact on } \\
\text { competition. Under fundamentally the same } \\
\text { supervisory mandate, a recent material } \\
\text { change from what the authorities described } \\
\text { as 'principles- based' to 'intensive and } \\
\text { intrusive,' 'judgment-based' supervision is } \\
\text { underway in response to experience in the } \\
\text { crisis. The full impact of the change will } \\
\text { occur over the next two years. There is a risk } \\
\text { that the mandate and objectives of the } \\
\text { various new agencies proposed, and how } \\
\text { they interact, will be unclear for some time. }\end{array}$ \\
\hline $\begin{array}{l}1.2 \text { Independence, accountability and } \\
\text { transparency }\end{array}$ & $\begin{array}{l}\text { The reasons for removal of the head of the } \\
\text { supervisory authority are not specified in } \\
\text { legislation, nor is there a requirement to } \\
\text { make those reasons public. The assessors } \\
\text { were not in a position to do a detailed } \\
\text { analysis, but their strong sense is that } \\
\text { additional resources for prudential regulation } \\
\text { and supervision are required (some } \\
\text { combination of enhanced skills and } \\
\text { additional people), while recognizing that } \\
\text { some of this could be funded from } \\
\text { efficiencies in existing processes that the } \\
\text { FSA is now assessing. }\end{array}$ \\
\hline 1.3 Legal framework & Compliance without comments. \\
\hline 1.4 Legal powers & Compliance without comments. \\
\hline 1.5 Legal protection & Compliance without comments. \\
\hline 1.6 Cooperation & Compliance without comments. \\
\hline 2. Permissible activities & Compliance without comments. \\
\hline 3. Licensing criteria & Compliance without comments. \\
\hline 4. Transfer of significant ownership & Compliance without comments. \\
\hline
\end{tabular}




\begin{tabular}{|c|c|}
\hline Core Principle & Comments \\
\hline 5. Major acquisitions & $\begin{array}{l}\text { A particular issue is that the power to review } \\
\text { acquisitions does not extend to acquisitions } \\
\text { by parent holding companies of banks. This } \\
\text { flows from issues identified and assessed in } \\
\text { CP } 24 \text {. }\end{array}$ \\
\hline 6. Capital adequacy & $\begin{array}{l}\text { Strengthening the quantity and quality of } \\
\text { capital is occurring, including through setting } \\
\text { individual capital guidance for banks above } \\
\text { the minimum, capital buffers through stress } \\
\text { testing, and the interim capital targets, which } \\
\text { are higher than the new Basel minimums. } \\
\text { Assessments of the use of advanced models } \\
\text { by banks to determine their capital position } \\
\text { (both qualitative and quantitative } \\
\text { requirements) are not sufficiently detailed. } \\
\text { This foundation needs to be in place, so } \\
\text { authorities can rely fully on the model results } \\
\text { for prudential purposes. }\end{array}$ \\
\hline 7. Risk management process & $\begin{array}{l}\text { Comprehensive enterprise-wide risk } \\
\text { measurement and risk management (ERM) } \\
\text { remains a challenge for some major banks. } \\
\text { The FSA's enhanced program of supervisory } \\
\text { assessment of ERM is just starting. } \\
\text { Programs to relate capital to risk are well } \\
\text { advanced. }\end{array}$ \\
\hline 8. Credit risk & $\begin{array}{l}\text { Assessment of credit risk management and } \\
\text { asset quality by the FSA needs to be } \\
\text { enhanced to include sufficient, timely, } \\
\text { proactive, and in-depth reviews as well as } \\
\text { some degree of transaction testing. } \\
\text { Specialist resources have been enhanced, } \\
\text { but an in-house and/or external on-site } \\
\text { approach to credit risk is also needed. Plans } \\
\text { to enhance data and analytics to perform } \\
\text { better peer comparisons are sound but need } \\
\text { to be executed. The Core Prudential } \\
\text { Program for credit risk has not yet been fully } \\
\text { rolled out and could not be assessed, } \\
\text { including an assessment of how much } \\
\text { detailed onsite credit risk assessment will } \\
\text { actually occur. A full roll-out is expected to } \\
\text { be completed by end-2012. }\end{array}$ \\
\hline
\end{tabular}




\begin{tabular}{|c|c|}
\hline Core Principle & Comments \\
\hline 9. Problem assets, provisions, and reserves & $\begin{array}{l}\text { Focus is placed on capital and not on } \\
\text { provisioning and reserves. New EU rules, } \\
\text { following revised IAS } 39 \text { (EL-driven), will } \\
\text { require a change in this approach. }\end{array}$ \\
\hline 10. Large exposure limits & $\begin{array}{l}\text { The FSA should encourage banks to set } \\
\text { stricter limits to large exposures as part of } \\
\text { sound risk-management practice. }\end{array}$ \\
\hline 11. Exposure to related parties & $\begin{array}{l}\text { The FSA relies on general rules to deal with } \\
\text { related-party issues, for which they are not } \\
\text { really tailored. This is supplemented with } \\
\text { supervisor discretion. These transactions } \\
\text { appear not to be sufficiently considered. }\end{array}$ \\
\hline 12. Country and transfer risks & $\begin{array}{l}\text { A more proactive approach to supervision } \\
\text { generally, as per CP } 19 \text {, would naturally } \\
\text { apply to country risk. }\end{array}$ \\
\hline 13. Market risks & $\begin{array}{l}\text { There is room for more proactive cross- } \\
\text { system, in-depth reviews of market risk using } \\
\text { the recently enhanced specialist resources, } \\
\text { linked to supervision processes under the } \\
\text { enhancement program; full compliance with } \\
\text { this principle is also affected by the } \\
\text { weaknesses in the supervisory approach } \\
\text { assessed in CP } 19 \text {. }\end{array}$ \\
\hline 14. Liquidity risk & $\begin{array}{l}\text { The FSA has made major and successful } \\
\text { efforts to ensure that very high-impact banks } \\
\text { increase their liquidity, and to enhance FSA } \\
\text { supervision. Further efforts are required, } \\
\text { including detailed drill-down supervisory } \\
\text { work for high-impact banks, as per current } \\
\text { plans. }\end{array}$ \\
\hline 15. Operational risk & $\begin{array}{l}\text { The FSA has a general thrust to encourage } \\
\text { large, sophisticated institutions to upgrade } \\
\text { their internal operational risk management. }\end{array}$ \\
\hline 16. Interest rate risk in the banking book & $\begin{array}{l}\text { There are deficiencies in reporting that } \\
\text { partially hinder outlier analysis for smaller } \\
\text { and mid-sized banks. }\end{array}$ \\
\hline 17. Internal control and audit & $\begin{array}{l}\text { The FSA is following the "Walker Review" } \\
\text { recommendations to improve bank } \\
\text { governance. }\end{array}$ \\
\hline 18. Abuse of financial services & $\begin{array}{l}\text { The FSA's use of risk-based methodology } \\
\text { means that smaller banks receive less on- } \\
\text { site anti-money laundering/combating the } \\
\text { financing of terrorism (AML/CFT) attention } \\
\text { than optimal. Attention also could be } \\
\text { increased on foreign branches of U.K. banks. }\end{array}$ \\
\hline
\end{tabular}




\begin{tabular}{|c|c|}
\hline Core Principle & Comments \\
\hline 19. Supervisory approach & 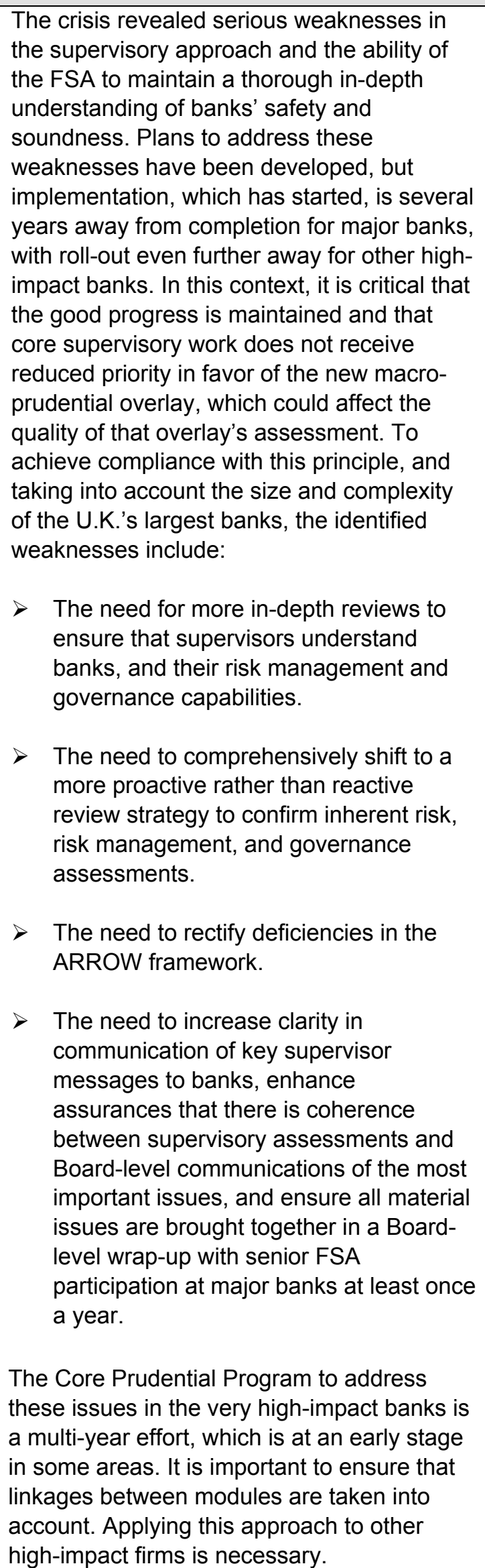 \\
\hline
\end{tabular}




\begin{tabular}{|c|c|}
\hline Core Principle & Comments \\
\hline 20. Supervisory techniques & $\begin{array}{l}\text { There is an unbalanced mix between what } \\
\text { would be commonly described as sound 'on- } \\
\text { site' and 'off-site' supervision, with less 'on- } \\
\text { site.' }\end{array}$ \\
\hline 21. Supervisory reporting & $\begin{array}{l}\text { To achieve full compliance, FSA supervisory } \\
\text { reporting would benefit from more regular } \\
\text { use of granular data on advanced bank } \\
\text { portfolios, which would better permit } \\
\text { identification of outliers and peer analysis. } \\
\text { Improved regular reporting from smaller and } \\
\text { mid-sized banks in select areas (e.g., } \\
\text { interest rate risk in the banking book } \\
\text { (IRRBB)) would also allow effective outlier } \\
\text { analysis. }\end{array}$ \\
\hline 22. Accounting and disclosure & $\begin{array}{l}\text { There is room to improve public disclosure } \\
\text { by banks. }\end{array}$ \\
\hline $\begin{array}{l}\text { 23. Corrective and remedial powers of } \\
\text { supervisors }\end{array}$ & $\begin{array}{l}\text { While the FSA generally has adequate } \\
\text { legislative powers, and there is evidence of } \\
\text { their use, there is no framework for early } \\
\text { intervention. That is being considered as part } \\
\text { of the new arrangements. }\end{array}$ \\
\hline 24. Consolidated supervision & $\begin{array}{l}\text { The FSA practices consolidated supervision, } \\
\text { including applying rules for such matters as } \\
\text { liquidity, capital, large exposures, risk } \\
\text { management and controls, and governance } \\
\text { of the whole banking group. However, the } \\
\text { legislation does not give the FSA formal } \\
\text { enforcement powers for these matters to be } \\
\text { applied at the parent bank holding company } \\
\text { level. Rather, powers only apply at the bank } \\
\text { or other authorized firms. This also affects } \\
\text { the FSA's ability to review acquisitions that } \\
\text { the parent bank holding company might } \\
\text { make in banks or other entities which are not } \\
\text { FSA-authorized firms. }\end{array}$ \\
\hline 25. Home-host relationships & $\begin{array}{l}\text { Appropriate legal authority to share } \\
\text { information and preserve confidentiality is in } \\
\text { place. There is room to improve the } \\
\text { information sharing between the United } \\
\text { Kingdom and other countries on both a home } \\
\text { and host basis. }\end{array}$ \\
\hline
\end{tabular}

Note: CP 1 is divided into six components for this analysis. 


\section{B. Recommended Action Plan and Authorities' Response}

\section{Table 2 lists the suggested steps for improving compliance. Recommendations} are proposed on a prioritized basis.

\section{Table 2. Recommended Action Plan to Improve Compliance with the Basel Core Principles}

\begin{tabular}{|c|c|}
\hline Reference Principle & Recommended Action \\
\hline 1.1 Responsibilities and objectives & $\begin{array}{l}\text { In the short run, clarify the objectives of intensive, } \\
\text { intrusive and judgment-based supervision. } \\
\text { Ensure management oversight focuses on } \\
\text { whether the on-ground activities are consistent } \\
\text { with the desired outcome. Ensure new mandates } \\
\text { in the reorganization are clear. }\end{array}$ \\
\hline $\begin{array}{l}19 \text { Supervisory approach } \\
20 \text { Supervisory techniques }\end{array}$ & $\begin{array}{l}\text { Develop an integrated multi-year plan for } \\
\text { enhanced supervision, including more on-site and } \\
\text { in-depth reviews, more peer benchmarking, a } \\
\text { desired coverage model that is more frequent, } \\
\text { and amendments to the risk-rating framework, so } \\
\text { that it is more discriminating, proactive, and } \\
\text { forward looking. This plan should include the } \\
\text { Core Prudential Program and its extension to a } \\
\text { range of banks beyond those that are very high- } \\
\text { impact (ultimately, all banks need a degree of } \\
\text { more in-depth proactive reviews). It should also } \\
\text { include risk-model changes. } \\
\text { Tighten specialist-supervisor linkages and } \\
\text { linkages between new initiatives (e.g., stress } \\
\text { testing of capital and liquidity). } \\
\text { Improve reporting of results to banks, so that they } \\
\text { get clear messages of the most important matters } \\
\text { that need to be dealt with. } \\
\text { Determine resource requirements for this new } \\
\text { model and a reasonable timeframe. } \\
\text { Ensure the new macro-prudential overlay does } \\
\text { not detract from delivering on this enhanced } \\
\text { micro-prudential core work. }\end{array}$ \\
\hline
\end{tabular}




\begin{tabular}{|c|c|}
\hline Reference Principle & Recommended Action \\
\hline 8 Credit Risk & $\begin{array}{l}\text { Develop a strategy for materially enhanced in- } \\
\text { depth review of credit risk, resource adequately } \\
\text { and execute, starting in } 2011 . \\
\text { Proceed with additional data gathering and } \\
\text { analytics to permit better peer analysis. } \\
\text { Consider multi-year plan to extend this approach } \\
\text { as necessary. } \\
\text { In the short term do more in-depth reviews of } \\
\text { commercial real estate exposures either using } \\
\text { FSA staff or skilled persons (Section } 166 \text { reports). }\end{array}$ \\
\hline 7 Risk management & $\begin{array}{l}\text { Implement the Core Prudential Program to } \\
\text { assess enterprise-wide risk management. } \\
\text { Ensure adequate review and assessment of } \\
\text { major banks' risk architecture and risk- } \\
\text { measurement capability. } \\
\text { Consider which smaller and mid-sized banks } \\
\text { should be subject to more-rigorous FSA stress } \\
\text { testing. } \\
\text { By end } 2011 \text {, review the adequacy of specialist } \\
\text { resources in light of then-current and expected } \\
\text { demands. }\end{array}$ \\
\hline 21 Supervisory reporting & $\begin{array}{l}\text { Develop a comprehensive plan to enhance } \\
\text { prudential reporting. }\end{array}$ \\
\hline 6 Capital adequacy & $\begin{array}{l}\text { Change the policy and provide adequate } \\
\text { resources to conduct a more in-depth review of } \\
\text { credit, market and AMA models. } \\
\text { Implement the announced policy to proactively } \\
\text { review the more important models on some } \\
\text { cycles, even if there are no changes that would } \\
\text { trigger a reactive review. } \\
\text { Consider extending this review beyond the } \\
10 \text { most important system-wide models. }\end{array}$ \\
\hline 14 Liquidity risk & $\begin{array}{l}\text { Continue with the planned roll-out of the new } \\
\text { approach beyond major banks. }\end{array}$ \\
\hline 13 Market risk & $\begin{array}{l}\text { Perform more in-depth proactive reviews, } \\
\text { including more regular peer analysis or 'theme' } \\
\text { reviews. }\end{array}$ \\
\hline 24 Consolidated supervision & $\begin{array}{l}\text { Amend legislation to give FSA powers over } \\
\text { holding companies of parent banks as a priority. }\end{array}$ \\
\hline
\end{tabular}




\begin{tabular}{|c|c|}
\hline Reference Principle & Recommended Action \\
\hline 25 Home-host relationships & $\begin{array}{l}\text { Work to enhance colleges and home-host } \\
\text { information sharing within the current framework. }\end{array}$ \\
\hline $\begin{array}{l}1.2 \text { Independence, accountability and } \\
\text { transparency }\end{array}$ & $\begin{array}{l}\text { Amend the Financial Services Market Act (FSMA) } \\
\text { to specify the conditions under which the FSA } \\
\text { head could be removed and provide for explicit } \\
\text { requirements to make these public. }\end{array}$ \\
\hline 5 Major Acquisitions & $\begin{array}{l}\text { Ensure that the FSA has the legal authority to } \\
\text { approve all financial institution acquisitions made } \\
\text { by parent bank holding companies (related to } \\
\text { CP 24). } \\
\text { Clarify the threshold for pre-notification in rules or } \\
\text { guidance. }\end{array}$ \\
\hline 23 Corrective and remedial powers of supervisors & $\begin{array}{l}\text { Enhance early intervention through developing } \\
\text { and promulgating an early intervention } \\
\text { framework. In the reorganization, include in the } \\
\text { FSMA a general objective of early intervention. }\end{array}$ \\
\hline 22 Accounting and disclosure & $\begin{array}{l}\text { Consider disclosing regularly a portion of } \\
\text { regulatory returns with suitable caveats that the } \\
\text { FSA is not responsible for their accuracy. }\end{array}$ \\
\hline 11 Exposure to related parties & $\begin{array}{l}\text { Consider developing more explicit rules. These } \\
\text { include (i) automatically defining more persons as } \\
\text { related parties consistent with this CP; } \\
\text { (ii) explicitly requiring transactions at market } \\
\text { value; and (iii) requiring that transactions above a } \\
\text { materiality threshold to be set by banks be } \\
\text { approved by a Board committee and with FSA } \\
\text { approval. Ensure adequate supervisory focus on } \\
\text { this as part of the reviews. }\end{array}$ \\
\hline 15 Operational risk & $\begin{array}{l}\text { Pursue a program to encourage major banks to } \\
\text { upgrade operational risk management capability. }\end{array}$ \\
\hline 17 Interest rate risk in the banking book & $\begin{array}{l}\text { Amend reporting to permit high-quality peer } \\
\text { analysis of this risk for smaller and mid-sized } \\
\text { banks. }\end{array}$ \\
\hline 18 Abuse of financial services & $\begin{array}{l}\text { Amend the risk-assessment methodology to } \\
\text { ensure adequate on-site coverage of smaller and } \\
\text { mid-sized banks for AML/CFT risk. Ensure } \\
\text { adequate on-site work (FSA or skilled persons) at } \\
\text { foreign branches of U.K. banks. }\end{array}$ \\
\hline
\end{tabular}

\section{Authorities' Response}

29. The U.K. authorities (HM Treasury, the BoE and the FSA) welcome this comprehensive IMF review of the United Kingdom's supervisory and regulatory 
framework for the banking sector. The assessment has come at an important time for the United Kingdom, as the transition to a new regulatory structure begins, and the authorities appreciate this opportunity to comment on it.

30. The report highlights that due to the domestic and global significance of the U.K.'s financial sector, the IMF review assesses the United Kingdom against a particularly high standard. Furthermore, this is a point in time assessment and therefore it has not been possible to give credit for a number of the supervisory reforms that are in train but not fully embedded.

31. As with many other major jurisdictions, the United Kingdom's supervisory and regulatory credibility was severely tested during the global financial crisis. The review recognizes that the FSA has responded to the crisis, making good progress on initiatives to enhance prudential requirements for banks and imposing a more intensive supervisory strategy. As the FSA has previously articulated, these supervisory reform programs will take time and there is still some way to go to fully implement them. The authorities are therefore pleased that the IMF recognizes that the FSA has made considerable progress on reforming its regulatory approach. The report also acknowledges that the continuing effective implementation of the reform programs will further improve the United Kingdom's compliance with the core principles.

32. The assessment concludes that supervisory judgments and actions taken since the crisis have been effective in identifying emerging risks in good time to enable the FSA to pro-actively manage them and, as such, the U.K. authorities believe that the FSA's supervisory approach is currently closer to compliance than the IMF has concluded. It is the authorities' intention that the new Prudential Regulation Authority's (PRA) approach to supervision will be based on this type of forward-looking judgment, clearly directing supervisory intervention at reducing the major risks to financial stability.

33. A theme running through the IMF's recommendations is that the current reform plans could be augmented, in particular through even deeper supervisory assessments of banks' key risk categories. The U.K. authorities believe that effective supervision should encompass three elements: policies and rules on firms' resilience (covering such areas as capital, liquidity and leverage); supervisory assessments and interventions; and policies and mechanisms to support resolution. It is the authorities' intention that the PRA will combine use of all these elements in order to effectively contribute to the financial stability of the United Kingdom.

34. The U.K. authorities want the PRA to be compliant with international supervisory standards and will consider the IMF recommendations carefully in the design of the operating model for the PRA. HM Treasury is already consulting on proposed legislative reforms that will go a long way to address a number of the identified gaps in the United Kingdom's regulatory framework. Most important of these is setting a 
single and clear mandate for the PRA to contribute to the promotion of the financial stability of the United Kingdom. The authorities concur with the IMF that a clear and focused mandate is the cornerstone of an effective regulatory regime. Other reforms include extending the regulatory perimeter to financial holding companies, and introducing a Proactive Intervention Framework.

\section{The PRA's future approach to regulation will certainly draw on current FSA} best practices, but will enhance and tailor them in way that is conducive to meeting the PRA's financial stability mandate. The PRA's approach will thus consist of policy making to guard against a range of possible outcomes and the application of that policy through effective supervision. All banks will be subject to a baseline level of supervisory oversight designed both to reduce the probability of failure and, as it is not the PRA's role to prevent bank failure, to ensure that if a bank does fail, it does so in an orderly manner. The PRA will not view orderly failure as regulatory failure. For those banks posing greater risk to the stability of the system, the PRA's supervisory approach will be more intensive and focused, including:

- $\quad$ analysis of a bank's financial position;

- $\quad$ ongoing evaluation of a bank's business model, capital and liquidity plans, governance and culture, risk management and controls, to understand key risks to financial stability;

- $\quad$ stress testing against a range of possible future states of the world;

- $\quad$ regular assessment of a firm's resolvability and the state of its resolution plans;

- $\quad$ regular contact between a firm's senior management and senior PRA management; and

- $\quad$ early and proactive supervisory interventions under the Proactive Intervention Framework designed to reduce risks to the stability of the system.

36. The report also mentions in several places that additional supervisory resources are likely to be required to continue to deliver on, and augment, planned enhancements to supervision and to develop the new macro-prudential overlay. The authorities agree that good progress should be maintained on core supervisory work, as the PRA's main contribution to macro-prudential policy will be on the position of individual banks and sectors and understanding their impact on the stability of the system. Therefore the FSA and the Bank of England are already assessing resource requirements through the process of designing the PRA's operating model. This assessment includes determining the desired intensity of supervisory assessments; defining how the macro-prudential overlay will work; and identifying efficiency savings through simplifying supervisory processes. 
37. Finally, the authorities wish to express their strong support for the role the FSAP plays in promoting the soundness of global financial systems and look forward to a continuing dialogue with the IMF and other global counterparts in seeking to improve the stability and effective supervision of the global financial system.

\section{IAIS Insurance Core Principles}

\section{A. Introduction}

38. This assessment takes into account the significant legislative changes and regulatory developments in the U.K. insurance sector since 2002. ${ }^{3}$ The United Kingdom participated in an initial FSAP in 2002, which included a formal assessment of the Insurance Core Principles (ICPs). The recommendations arising from the 2002 assessment have been largely addressed, although one area, market disclosure, remains in need of improvement.

39. The initial FSAP was benchmarked against the ICPs issued in 2000, while the current assessment is benchmarked against the ICPs issued in 2003. The change in methodology, as well as the long period that has elapsed since the last FSAP, makes this assessment a full new assessment rather than an update. The impact of the Tiner report, the Northern Rock internal report, the Equitable enquiry, and the 2008 crisis has resulted in the strengthening of insurance sector supervision, which the assessors have noted by way of comments, where appropriate. The current assessment also took account of the relevant International Association of Insurance Supervisors (IAIS) standards and guidance that complement the ICPs.

40. The sophistication and importance of the U.K. insurance sector have been taken into consideration in determining the level of observance for each ICP; however, as is common practice, the assessment reflects the essential criteria only. Advanced criteria are not taken into consideration in assessing observance of the ICPs, but the supervisory demands for a complex and highly developed insurance sector are reflected in a stringent assessment of the ICPs.

41. The assessment is based solely on the laws, regulations, and other supervisory requirements and practices in place at the time of the assessment. This is particularly relevant in the context of the transition that the supervisory regime is currently undergoing with the dissolution of the FSA and the creation of two new entities. Thus, the assessment is based on the FSA as of the date of the assessment. Ongoing regulatory initiatives are noted by way of additional comments.

\footnotetext{
3 The assessment was conducted from January 17 to 31, 2011 by Mr. Tom Karp, Insurance Supervision Advisor contracted by the IMF, and Dr. Rodolfo Wehrhahn, Technical Assistance Advisor from the IMF.
} 
42. The major source of information used for the assessment is a comprehensive self-assessment carried out by the FSA. The assessors also made use of information on the FSA website, including numerous consultation papers, presentation material provided by the FSA officers, statistical information provided by the Association of British Insurers (ABI) and rating agencies, and background information available from various professional firms and international industry intelligence services. In addition, extensive interviews were conducted with numerous officers in the FSA and the various trade associations, major insurers, including Lloyds of London, and governmental and regulatory bodies concerned with standard setting, education, and consumer protection. The assessment team wishes to thank all concerned for their time and cooperation, which added significantly to the effectiveness of the assessment.

\section{B. Key Findings and Recommendations}

43. The conditions for effective supervision are adequately met, reflecting the highly developed legal system, institutional framework, financial markets, and long-standing insurance market. The United Kingdom has been heavily involved in developing Solvency II requirements and has positioned itself well for effective implementation. The United Kingdom is also contributing significantly to international developments in financial regulation, which have been moving more rapidly since the financial crisis. However, overreliance on European Union (EU) and international developments as the prime drivers for change risks missing changes that are needed due to local market weaknesses or developments.

44. Insurance regulation in the United Kingdom is thorough and effective. Insurance regulation and supervision were strengthened following financial market turbulence around 2003-04. This helped the insurance sector to come through the more recent financial crisis in reasonable shape with no government financial aid being required.

\section{The powers given to the FSA under the Financial Services Market Act have} allowed it to develop comprehensive and detailed regulatory requirements and supervision guidance. The substantial FSA Handbook containing regulations and detailed guidance is kept up to date with current market developments and supervisory needs. Changes and additions to regulation and supervision undergo a transparent consultative process before implementation.

46. As a consolidated supervisor, the FSA has been able to use economies of scale. A well-developed and consistent set of centralized functions for common supervisory activities across the financial sectors is in place, and access to experts in different financial sector areas is internally available. It is recommended that due regard be given to maintaining the high standards of the currently centralized activities, such as licensing, fit-and-proper assessments, changes in control, and fraud detection, when restructuring the supervisory authority. 
47. The change in the last three years in intensity, intrusiveness, and supervisory quality cannot escape our analysis. Issues that were tolerated or ignored in the past have been discovered and dealt with in an effective and forceful way. Supervision has become intrusive and intensive in certain areas and for the high-risk firms. Initiatives like the Core Prudential Program for Insurers (CPPI) and Solvency II preparatory work are to be commended. However, these initiatives have not been fully completed, and thus further work is required so that the supervisory analysis and thinking it entails can be embedded into the processes and expertise of the FSA. This analysis should be extended to a wider range of insurers, but this will need careful adjustment to ensure it is applied proportionately to firms of various impacts, especially in respect of the key financial risks and associated 'deep dives' when applied to general insurers. It will clearly involve extra resources.

\section{The FSA applies a sophisticated and well-developed risk-based approach to} supervision based on the ARROW. This approach, which provides for the effective allocation of resources to the issues that present high risk to the FSA objectives, is complemented by thematic supervision that applies to the whole spectrum of the supervised entities. Supplementing its risk-based and thematic approach, the FSA sometimes conducts a 'transaction examination.' This brings to the surface unknown (to both the FSA and the insurer) problems, so it is an effective complement to top-down-driven examinations. When insurers are aware that the FSA occasionally undertakes such examinations, it also becomes a force for keeping insurers on their toes, rather than having them concentrate on areas where they think on-site work will occur. The FSA should ensure that the further development of its approach to supervision maintains an emphasis on random 'transaction examinations' (in relevant areas such as underwriting, reinsurance, claims, and even investments) covering both the largest insurers and even some smaller insurers.

\section{The more modern and risk-sensitive capital requirements brought about by} Solvency II should be public to provide a more appropriate view of firms' financial position compared with Solvency I metrics. The granularity, scope, and appropriate frequency of data availability in carrying out the suitable level of supervision are currently only achieved in a reactive fashion. While the information that must be disclosed has been improved and updated, no comprehensive revision has been undertaken for a number of years. This is predominantly because EU developments on Solvency II have been ongoing for a few years and it was clear that, when introduced, they would significantly change and increase the data that insurers would be required to disclose. The FSA, as a response to its urgent need to acquire a more realistic view of the firms' financial position in the complex insurance market, introduced Internal Capital Assessments (ICAs) along with the reporting of realistic balance sheets for large with-profits funds in 2004. At present, this additional valuable knowledge of the financial position of the company does not have to be made public, but this will change with the implementation of Solvency II. However, it would have been beneficial to the system if suitable data requirements consistent with the complexity of the market had been implemented at an earlier stage. 


\section{Conditions for Effective Insurance Supervision (ICP 1)}

50. The conditions for effective supervision are met and several areas follow best international practice, reflecting the highly developed legal system, institutional framework, financial markets, and long-standing insurance market. The United Kingdom's well-developed judicial system has a reputation for probity and professionalism. The long history of insurance actions and settlements in the United Kingdom means that there is a substantial body of insurance case law and considerable experience, both within the judiciary and on the practitioners' side, in addressing complex insurance law disputes. The Institute and Faculty of Actuaries, now the combined professional body for U.K. actuaries, has an impeccable international reputation. The accounting, actuarial, and auditing standards are publicly available on the organization's website and they are commensurate with international standards. The Office of National Statistics produces a variety of economic, social, and financial statistics, which are readily available on the internet. The BoE publishes a Financial Stability Report in June and December each year, which gives an overview of the key developments affecting the U.K. financial system.

\section{The Supervisory System (ICP 2 to ICP 5)}

51. While there is clarity in the statutory objectives, it is necessary to clarify which prudential objectives are the primary ones and which are the secondary. The principles of good regulation refer to maintaining the competitive position of the United Kingdom and to facilitating competition. Thus, it is unclear where the desired balance between the important objectives of financial stability and market confidence (which is meant to be essentially financial soundness) on the one hand and competition, on the other, should lie. The supervisory approach of the FSA in its earlier years and its public statements indicate that financial sector firms were given considerable freedom to compete in the market, with the FSA only intervening when problems arose. The more recent inclusion of the objective of financial stability is helpful in achieving a rebalance, but it would be more helpful if it was made clearer that market confidence and financial stability were the primary prudential objectives with financial innovation and competition secondary. Clarity on this would help significantly in achieving the correct culture within a prudential regulator.

52. The FSA has adequate powers and protections to exercise its functions. It also has a very high degree of operational independence, but is subject to numerous and adequate accountability mechanisms. For example, it has to demonstrate that it is exercising its powers and functions appropriately and effectively. Transparency and accountability in the supervisory process are at international levels.

53. Recent developments have highlighted the need for greater attention to be given to staffing issues. Over the last two years, the FSA has been able to recruit a significant number of actuaries for its life and general insurance actuarial teams, but also to dramatically increase its actuarial modeling expertise, which is needed for its implementation of Solvency 
II. However, the current level of uncertainty around the precise form of the new financial regulatory entity could be a destabilizing factor. Some senior insurance staff is leaving and there is a considerable risk that the vacuum thus created will only exacerbate the uncertainty, resulting in more staff losses. Consideration should be given to further strengthening the retention of expertise.

54. The lack of a formal requirement to detail the circumstances in which the chairman or other Board members could be removed from office does not meet one of the essential criteria of the ICP 2. However, in practice, the arbitrary removal of the chairman would give rise to strong questioning by parliament as the independence of the FSA is legally established.

\section{E. The Supervised Entities (ICP 6 to ICP 10)}

55. The FSA has an effective centralized approach to key supervisory functions, such as licensing, fit and proper assessments, changes in control, and fraud detection. The FSA is very robust in its assessment and treatment of oversight and governance of insurance firms. In addition, the requirements for insurers to have adequate internal controls are comprehensive and detailed under ARROW. From viewing a few ARROW packs, it is clear that the FSA assesses internal control mechanisms and requires rectification where these are inadequate.

\section{F. Ongoing Supervision (ICP 11 to ICP 17)}

56. ARROW provides a well-structured approach to risk-based supervision through its use of firms' impact and probability ratings. The impact rating determines the minimum amount of supervisory work to be undertaken, and the firm's probability rating determines the amount of additional supervisory work to deal with identified specific risks and issues in the firm. ARROW findings, assessments, and the desired supervisory outcomes, including how and when they should be achieved, are made clear to firms.

57. The introduction of the CPPI was a good step toward gaining a deeper understanding of the major life insurers, in particular how sustainable, financially resilient, and well governed and managed they are. CPPI provides a greater degree of forward looking supervision, and thus has greater preventative capacity than the analysis and risk assessment techniques applied outside of CPPI. The FSA should ensure that the further development of its on-site inspection activity approach to supervision maintains an emphasis on random 'transaction examinations' (in relevant areas such as underwriting, reinsurance, claims, and even investments), covering both the largest insurers and some smaller insurers. This will often bring to the surface unknown (to both the FSA and the insurer) problems. It will clearly involve extra resources. 


\section{G. Prudential Requirements (ICP 18 to ICP 23)}

58. Paving the way for the implementation of Solvency II, the FSA has been working over the last 18 months with a large team of experts and a substantial budget. The implementation schedule is on target for 2013 and will result in a more risk-sensitive and robust solvency regime, transforming current pillar 2 recommendations into pillar 1 requirements.

\section{H. Markets and Consumers (ICP 24 to ICP 27)}

59. The United Kingdom can be seen as practicing international best practice in the area of consumer protection.

60. The published standard return information has not been comprehensively revised for a number of years, even though it has been updated and improved. Current enhanced capital requirements and realistic balance sheets for large with-profit insurers have been made public, but additional valuable knowledge of the financial position from insurers' individual capital assessments under ICAS has not had to be made public.

\section{Anti-Money Laundering/Combating the Financing of Terrorism (ICP 28)}

61. The AML/CFT requirements applicable to insurers are broadly in line with the FATF recommendations. However, there is scope for improvement in the supervision of smaller firms and foreign branches.

Table 3. Summary of Observance of the Insurance Core Principles-Detailed Assessments

\begin{tabular}{|l|l|}
\hline \multicolumn{1}{|c|}{ Insurance Core Principle } & \multicolumn{1}{c|}{ Comments } \\
\hline $\begin{array}{l}\text { ICP 1-Conditions for effective insurance } \\
\text { supervision }\end{array}$ & $\begin{array}{l}\text { Best international practice for several } \\
\text { essential criteria. }\end{array}$ \\
\hline ICP 2 -Supervisory objectives & $\begin{array}{l}\text { The tension between the current } \\
\text { objectives and some of the principles of } \\
\text { good regulation risk compromising or } \\
\text { slowing down prudential action. Although } \\
\text { we have seen no direct evidence of this, it } \\
\text { can impact the organization's culture. In } \\
\text { particular, the requirement for the FSA to } \\
\text { have regard to the "desirability to } \\
\text { maintain the competitive advantage of the } \\
\text { United Kingdom" as well as "the need to } \\
\text { minimize the effects on competition" } \\
\text { appear to be competing with the market } \\
\text { confidence objective and there is no } \\
\text { indication of how these two issues are } \\
\text { supposed to be balanced. The more }\end{array}$ \\
\hline
\end{tabular}




\begin{tabular}{|c|c|}
\hline Insurance Core Principle & Comments \\
\hline & $\begin{array}{l}\text { recent inclusion of the objective of } \\
\text { financial stability is helpful in achieving a } \\
\text { rebalance (FSMA does show the primacy } \\
\text { of the financial stability objective, as it is a } \\
\text { regulatory objective while the principles of } \\
\text { good regulation are factors which the } \\
\text { FSA 'must have regard to' in discharging } \\
\text { its duties (FSMA } 2 \text { (3)). However, it would } \\
\text { be more helpful if it was made clearer that } \\
\text { market confidence and financial stability } \\
\text { were the prime prudential objectives with } \\
\text { financial innovation and competition } \\
\text { secondary. It should also be clarified that } \\
\text { market confidence is essentially about } \\
\text { financial soundness and prudential } \\
\text { regulation. } \\
\text { The consumer protection objective is also } \\
\text { an important objective, but can often be } \\
\text { interpreted as being mostly about } \\
\text { fostering an environment in which } \\
\text { potential customers can obtain good } \\
\text { deals through strong competition. } \\
\text { Consumer protection in a prudential } \\
\text { regulation context is actually more about } \\
\text { maintaining the financial soundness of } \\
\text { firms so that they can deliver to } \\
\text { customers the promises embodied in their } \\
\text { products. Clarity on this helps significantly } \\
\text { in judging the performance of the } \\
\text { prudential regulator. }\end{array}$ \\
\hline ICP 3-Supervisory authority & $\begin{array}{l}\text { Essential criterion e is not observed as } \\
\text { there are no requirements to make public } \\
\text { the circumstances in which the chairman } \\
\text { or other Board members could be } \\
\text { removed from office. However, in practice } \\
\text { arbitrary removal of the chairman would } \\
\text { give rise to strong questioning by } \\
\text { parliament as the independence of the } \\
\text { FSA is legally established. } \\
\text { The current level of uncertainty around } \\
\text { the precise form of the new financial } \\
\text { regulatory arrangements, and what the } \\
\text { remit, culture and supervisory approach } \\
\text { of the new financial regulatory bodies is } \\
\text { likely to be or could be a destabilizing } \\
\text { factor. Some senior insurance staff is } \\
\text { leaving and there is a considerable risk }\end{array}$ \\
\hline
\end{tabular}




\begin{tabular}{|c|c|}
\hline Insurance Core Principle & Comments \\
\hline & $\begin{array}{l}\text { that the vacuum thus created will only } \\
\text { exacerbate the uncertainty, resulting in } \\
\text { more staff losses. Consideration should } \\
\text { be given to further strengthening retention } \\
\text { of expertise. }\end{array}$ \\
\hline ICP 4-Supervisory process & $\begin{array}{l}\text { Transparency and accountability in the } \\
\text { supervisory process are at international } \\
\text { levels. }\end{array}$ \\
\hline $\begin{array}{l}\text { ICP 5-Supervisory cooperation and information } \\
\text { sharing }\end{array}$ & $\begin{array}{l}\text { Essential criteria g and i are [largely] } \\
\text { observed. There are formal requirements } \\
\text { for the FSA to consult with other } \\
\text { European Economic Area (EEA) } \\
\text { supervisors before taking action in certain } \\
\text { scenarios. In addition, this policy is } \\
\text { embedded in the FSA's ARROW, which } \\
\text { supervisors use in relation to all firms } \\
\text { (chapter } 5 \text {, ARROW Toolkit, tool } 7 \\
\text { implements how to contact a non-U.K. } \\
\text { regulator/supervisory authority for the } \\
\text { purposes of ARROW firms work in } \\
\text { relation to assessment, mitigation and } \\
\text { remedial action). } \\
\text { Going forward, the FSA is also engaged } \\
\text { in international developments such as: } \\
\text { Solvency II Directive, which will } \\
\text { introduce legal obligations for EEA } \\
\text { supervisors to work together in the } \\
\text { supervision of insurance groups to } \\
\text { ensure timely cooperation, exchange } \\
\text { of information and consultation } \\
\text { among them (i.e., the adoption of } \\
\text { remedial actions, etc). This Directive } \\
\text { is expected to be implemented by } \\
\text { January } 12,2012 ; \text { and } \\
\text { the IAIS, where the United Kingdom } \\
\text { has applied to be a party to the IAIS } \\
\text { Multilateral Memorandum of } \\
\text { Understanding (MMOU), which will } \\
\text { facilitate the exchange of information } \\
\text { and cooperation with foreign } \\
\text { supervisors (essentially non-EEA } \\
\text { regulators). }\end{array}$ \\
\hline ICP 6-Licensing & $\begin{array}{l}\text { The licensing requirements are } \\
\text { numerous, detailed and transparent. The } \\
\text { licensing process is carried out by a } \\
\text { central authorizations area within the FSA } \\
\text { with input from the firm's assigned FSA }\end{array}$ \\
\hline
\end{tabular}




\begin{tabular}{|c|c|}
\hline Insurance Core Principle & Comments \\
\hline & $\begin{array}{l}\text { supervisors. Assessments of applications } \\
\text { are thorough without causing undue } \\
\text { delay. } \\
\text { There is a risk that the licensing process } \\
\text { in the new structure might not be as } \\
\text { thorough and consistent. }\end{array}$ \\
\hline ICP 7-Suitability of persons & $\begin{array}{l}\text { The U.K. regime for suitability of persons } \\
\text { is very strong, with both high } \\
\text { requirements and a rigorous approval } \\
\text { process. This process has been made } \\
\text { more robust after the financial crisis } \\
\text { through numerous FSA interviews of } \\
\text { candidates for senior roles in insurers. } \\
\text { There is a risk that the rigor in this } \\
\text { process and the robustness of the } \\
\text { suitability of persons' regime may be } \\
\text { difficult to preserve in the new structure. }\end{array}$ \\
\hline ICP 8-Changes in control and portfolio transfers & $\begin{array}{l}\text { As with authorizations, the United } \\
\text { Kingdom has a robust regime for changes } \\
\text { of control, which are applied thoroughly } \\
\text { and with disregard to external pressure. } \\
\text { The current structure allows the FSA to } \\
\text { draw on expert staff in dealing with this } \\
\text { type of regulatory transaction or other } \\
\text { specialist advice (risk, actuaries, and } \\
\text { legal) when needed. Processes and } \\
\text { requirements are well documented and } \\
\text { applied. } \\
\text { There is a risk that in the new structure } \\
\text { access to such specialist staff and robust } \\
\text { processes might be challenging. }\end{array}$ \\
\hline ICP 9-Corporate governance & $\begin{array}{l}\text { The FSA is very robust in its assessment } \\
\text { and treatment of oversight and } \\
\text { governance of insurance firms. }\end{array}$ \\
\hline ICP 10-Internal controls & $\begin{array}{l}\text { The FSA requirements for insurers to } \\
\text { have adequate internal controls are } \\
\text { comprehensive and detailed under } \\
\text { ARROW. They also make clear that } \\
\text { ultimate responsibility lies with the Board } \\
\text { of Directors. From viewing a few ARROW } \\
\text { packs, it is clear that the FSA robustly } \\
\text { assesses internal control mechanisms } \\
\text { and requires rectification where these are } \\
\text { inadequate. }\end{array}$ \\
\hline ICP 11-Market analysis & $\begin{array}{l}\text { Through the establishment and } \\
\text { substantial growth of the FSA's Insurance }\end{array}$ \\
\hline
\end{tabular}




\begin{tabular}{|c|c|}
\hline Insurance Core Principle & Comments \\
\hline & $\begin{array}{l}\text { Sector Team, an impressive capability } \\
\text { exists to conduct quality market analysis } \\
\text { and link it to supervisory objectives and } \\
\text { outcomes. } \\
\text { There is effective communication to } \\
\text { industry and senior people in insurance } \\
\text { firms of the industry key risks, issues and } \\
\text { trends indentified through these } \\
\text { processes. } \\
\text { The IST financial analysis reports are } \\
\text { primarily based on statutory accounts } \\
\text { data, so there is limited reliance on the } \\
\text { FSA returns. } \\
\text { These reports provide a different } \\
\text { perspective to supervisors to complement } \\
\text { their review of annual returns. This } \\
\text { approach allows the FSA to update the } \\
\text { analysis during the year, e.g., on half } \\
\text { yearly and quarterly bases. } \\
\text { Financial analysis is supplemented by } \\
\text { other timely updates on emerging issues, } \\
\text { some of which will involve gathering } \\
\text { financial data (e.g., a recent motor market } \\
\text { survey, and the analysis of and a } \\
\text { commentary on reinsurance renewals } \\
\text { that is currently underway). Additionally, } \\
\text { the IST tracks and monitors external } \\
\text { market commentary, analyzes, and } \\
\text { forwards them to relevant areas in } \\
\text { supervision and other insurance areas of } \\
\text { the FSA on a timely basis. } \\
\text { Shortening the time to "market" of the IST } \\
\text { reports should be considered to make } \\
\text { them even more effective. }\end{array}$ \\
\hline $\begin{array}{l}\text { ICP } 12 \text {-Reporting to supervisors and off-site } \\
\text { monitoring }\end{array}$ & $\begin{array}{l}\text { There is substantial return information } \\
\text { required to be produced, certified, } \\
\text { audited, and lodged with the FSA. This } \\
\text { has been supplemented with additional } \\
\text { required information as needed given the } \\
\text { type and size of insurer and as its } \\
\text { financial and organizational position } \\
\text { changes. } \\
\text { While there have been improvements and } \\
\text { updates, there has not been a } \\
\text { comprehensive revision of the standard }\end{array}$ \\
\hline
\end{tabular}




\begin{tabular}{|c|c|}
\hline Insurance Core Principle & Comments \\
\hline & $\begin{array}{l}\text { return information required of insurers for } \\
\text { a number of years. This is predominantly } \\
\text { because EU developments on Solvency II } \\
\text { have been ongoing for a few years and it } \\
\text { was clear that when introduced they } \\
\text { would significantly change and increase } \\
\text { the data insurers would be required to } \\
\text { lodge with insurance supervisors. } \\
\text { It is recommended that the FSA } \\
\text { continue to contribute to the } \\
\text { finalization of Solvency II data } \\
\text { requirements and work now to } \\
\text { position itself and its insurers for } \\
\text { timely implementation of these data } \\
\text { requirements. }\end{array}$ \\
\hline ICP 13-On-site inspection & $\begin{array}{l}\text { ARROW provides a well-structured } \\
\text { approach to risk-based supervision } \\
\text { through its use of firm impact ratings, } \\
\text { which drive the minimum amount of } \\
\text { supervisory work and the firm's } \\
\text { probability rating, which drives the } \\
\text { amount of additional supervisory work to } \\
\text { deal with identified specific risks and } \\
\text { issues in the firm. ARROW therefore is } \\
\text { the driver of the amount of and type of } \\
\text { on-site work, which is conducted on an } \\
\text { individual insurer. } \\
\text { The FSA process for planning on-site } \\
\text { reviews and finalizing ARROW } \\
\text { assessments is thorough and requires a } \\
\text { substantial amount of thinking and } \\
\text { challenge from outside the direct } \\
\text { supervisory team, including from risk and } \\
\text { sector specialists and senior supervisory } \\
\text { executives. } \\
\text { The introduction of the CPPI was a good } \\
\text { step toward getting a deeper } \\
\text { understanding of the major life insurers. } \\
\text { The CPPI needs to be continued to } \\
\text { embed the supervisory analysis and } \\
\text { thinking it entails into the processes and } \\
\text { expertise of the FSA. The CPPI should be } \\
\text { extended to a wider range of insurers, but } \\
\text { this will need careful adjustment to } \\
\text { ensure it is applied proportionately to } \\
\text { firms of various impacts, especially in }\end{array}$ \\
\hline
\end{tabular}




\begin{tabular}{|c|c|}
\hline Insurance Core Principle & Comments \\
\hline & $\begin{array}{l}\text { respect of the key financial risks and } \\
\text { associated 'deep dives' when applied to } \\
\text { general insurers. It will clearly involve } \\
\text { extra resources. } \\
\text { Some of the on-site reviews related to } \\
\text { risks and controls and thematic reviews } \\
\text { have examined representative samples of } \\
\text { individual transactions (e.g., looking at } \\
\text { the underwriting files of some commercial } \\
\text { risks in an insurer). Such 'transaction } \\
\text { examination' is highly effective in } \\
\text { establishing if the control mechanisms } \\
\text { around a particular risk are actually } \\
\text { working to ensure that the risk is properly } \\
\text { managed in accordance with the policy } \\
\text { and controls laid down by the insurer. } \\
\text { Deep dives or Financial Risk Reviews } \\
\text { (FRR), carried out as part of CPPI, are } \\
\text { not triggered by particular concerns or } \\
\text { specific risk drivers, but are carried out } \\
\text { periodically. The FRR, which looks at } \\
\text { intra group exposures and risk transfers, } \\
\text { typically reviews key reinsurance treaties } \\
\text { in detail. On the nonlife side, the FSA } \\
\text { undertakes file reviews as part of } \\
\text { ARROW assessments or on an ad hoc } \\
\text { basis. } \\
\text { The FSA's use of such 'transaction } \\
\text { examination' is sometimes driven from a } \\
\text { top-down assessment of inherent risks } \\
\text { and any concerns arising from other } \\
\text { sources of information (e.g., complaints, } \\
\text { risks, and audit reports). The FSA also } \\
\text { requires firms to commission investigative } \\
\text { work from a skilled person (skilled person } \\
\text { (FSMA section } 166 \text { ) reports). This can be } \\
\text { risk-specific but can also cover more } \\
\text { general insurance activity. } \\
\text { The FSA's thematic projects often involve } \\
\text { file reviews. } \\
\text { Some of the on-site inspections are } \\
\text { relatively recent, arising from an increase } \\
\text { in the intensity of the FSA's supervisory } \\
\text { approach. The FSA should ensure that } \\
\text { maintains an emphasis on random } \\
\text { 'transan examinations' (in relevant }\end{array}$ \\
\hline
\end{tabular}




\begin{tabular}{|c|c|}
\hline Insurance Core Principle & Comments \\
\hline & $\begin{array}{l}\text { areas such as underwriting, reinsurance, } \\
\text { claims, and even investments) on both } \\
\text { the largest insurers and some smaller } \\
\text { insurers. } \\
\text { This will often bring to the surface } \\
\text { unknown (to both the FSA and the } \\
\text { insurer) problems, so it is an effective } \\
\text { complement to top-down driven } \\
\text { examinations. When insurers are aware } \\
\text { that the FSA undertakes such } \\
\text { examinations, it also becomes a force for } \\
\text { keeping insurers on their toes rather than } \\
\text { having them concentrate on areas where } \\
\text { they think on-site work will occur. }\end{array}$ \\
\hline ICP 14-Preventive and corrective measures & $\begin{array}{l}\text { The FSA processes flowing from ARROW } \\
\text { assessments and ongoing supervisory } \\
\text { monitoring appear to be adequate to } \\
\text { provide confidence that the supervisory } \\
\text { action that was decided on is taken and } \\
\text { firm, required actions are followed up. } \\
\text { Consideration should be given to } \\
\text { developing a more structured framework } \\
\text { for the types of remedial action that } \\
\text { should generally be considered and taken } \\
\text { for each, or at least for the most common, } \\
\text { ARROW assessment outcomes. This } \\
\text { would assist supervisory staff in } \\
\text { developing supervisory responses and, } \\
\text { over time, could reduce the reliance on } \\
\text { the expertise of the senior people } \\
\text { involved in panels and other review } \\
\text { mechanisms. }\end{array}$ \\
\hline ICP 15-Enforcement or sanctions & $\begin{array}{l}\text { Sanctions and enforcement are actively } \\
\text { used when needed by the FSA to achieve } \\
\text { corrective action and to act as a deterrent } \\
\text { to others. A wide range of sanctions are } \\
\text { available, including variations of } \\
\text { permission, directions, fines, public } \\
\text { censure, disqualifications, and removal of } \\
\text { authorizations. } \\
\text { The FSA does not have the power to } \\
\text { arrange for a compulsory transfer of the } \\
\text { obligations under the policies from a } \\
\text { failing insurer to another willing insurer. } \\
\text { However, it can facilitate the transfer } \\
\text { where appropriate and where there is a } \\
\text { willing transferee. }\end{array}$ \\
\hline
\end{tabular}




\begin{tabular}{|c|c|}
\hline Insurance Core Principle & Comments \\
\hline ICP 16-Winding-up or exit from the market & $\begin{array}{l}\text { There are clear provisions for the exit and } \\
\text { winding up of insurers in the United } \\
\text { Kingdom. Policyholders have preference } \\
\text { in a windup over other creditors except } \\
\text { employees. Where ultimately an insurer's } \\
\text { claims cannot be paid, the FSCS would } \\
\text { compensate eligible claimants (generally } \\
\text { individuals and small businesses) for } \\
\text { losses up to } 90 \text { percent of the value of } \\
\text { their insurance contract ( } 100 \text { percent in } \\
\text { the case of compulsory insurances). }\end{array}$ \\
\hline ICP 17-Group-wide supervision & $\begin{array}{l}\text { The FSA supervises insurance groups } \\
\text { and financial conglomerates as a } \\
\text { supplement to solo supervision of } \\
\text { insurers and reinsurers, in accordance } \\
\text { with the European Insurance Groups } \\
\text { Directive (IGD) and Financial } \\
\text { Conglomerates Directive (FCD). } \\
\text { Effective requirements exist for group } \\
\text { capital, financial reporting, material intra- } \\
\text { group transactions and risk and control } \\
\text { systems to assess intra-group risks. } \\
\text { The FSA leads or participates in } \\
\text { supervisory colleges for insurance groups } \\
\text { and financial conglomerates and, in } \\
\text { recent years, it has taken on its home } \\
\text { supervision role in a more intensive way, } \\
\text { conducting inspections of branches } \\
\text { outside the United Kingdom; thus gaining } \\
\text { a better understanding of the whole group } \\
\text { operation. } \\
\text { The FSA has no direct jurisdiction to } \\
\text { supervise unregulated holding companies } \\
\text { and needs to operate indirectly through } \\
\text { the regulated entities thus adding } \\
\text { complexity to their supervision and } \\
\text { monitoring activities of groups. }\end{array}$ \\
\hline ICP 18-Risk assessment and management & $\begin{array}{l}\text { The recently introduced CPPI, including } \\
\text { the deep dives as well as the allocation of } \\
\text { more resources, has brought to light } \\
\text { additional internal control weaknesses in } \\
\text { a few companies. These have been } \\
\text { addressed and corrections enforced. }\end{array}$ \\
\hline ICP 19-Insurance activity & $\begin{array}{l}\text { The for-profits business has been under } \\
\text { close supervision for several years with } \\
\text { respect to all technical aspects, such as }\end{array}$ \\
\hline
\end{tabular}




\begin{tabular}{|c|c|}
\hline Insurance Core Principle & Comments \\
\hline & $\begin{array}{l}\text { reserving and investment strategies. In } \\
\text { the last few years, with the increased } \\
\text { resources in the supervisory and actuarial } \\
\text { areas as well as the introduction of } \\
\text { ARROW } 2 \text { and CPPI, the FSA has } \\
\text { focused more intensively on pricing and } \\
\text { underwriting deficiencies. The results and } \\
\text { actions taken to monitor and enforce } \\
\text { compliance by insurers with the insurance } \\
\text { risk-management requirements in the last } \\
\text { few years led to the observance of this } \\
\text { principle. } \\
\text { The authorities are recommended to } \\
\text { maintain the momentum and focus on the } \\
\text { actuarial and supervisory activity in order } \\
\text { to be fully compliant with this principle. }\end{array}$ \\
\hline ICP 20-Liabilities & $\begin{array}{l}\text { The reporting forms required by the FSA } \\
\text { have added detail and increased the } \\
\text { scope of the data in the last few years as } \\
\text { a result of the introduction of realistic } \\
\text { balance sheets for with-profits business } \\
\text { and enhanced capital requirements, using } \\
\text { realistic valuations more generally. } \\
\text { Individual Capital Adequacy Standards } \\
\text { (ICAS) has also introduced risk sensitivity } \\
\text { and economic aspects to the valuation of } \\
\text { liabilities and technical provisions. } \\
\text { Further, if needed, the FSA has } \\
\text { successfully requested additional data } \\
\text { with higher frequency. } \\
\text { The ability to request needed data } \\
\text { together with the additional resources in } \\
\text { the actuarial and supervisory areas } \\
\text { allows the FSA to gain a fair } \\
\text { understanding of the adequacy of the } \\
\text { technical provisions and to take timely } \\
\text { action if required. } \\
\text { Adequacy of liabilities for long-term } \\
\text { business needs the opinion of a qualified } \\
\text { actuary. This requirement should be } \\
\text { extended to the GI liabilities. }\end{array}$ \\
\hline ICP 21-Investments & $\begin{array}{l}\text { The FSA meets all criteria of this } \\
\text { principle. }\end{array}$ \\
\hline ICP 22-Derivatives and similar commitments & International best practice \\
\hline ICP 23-Capital adequacy and solvency & $\begin{array}{l}\text { As a supplement to the current Solvency I } \\
\text { regime, the FSA has introduced resilience }\end{array}$ \\
\hline
\end{tabular}




\begin{tabular}{|c|c|}
\hline Insurance Core Principle & Comments \\
\hline & $\begin{array}{l}\text { capital requirements and realistic balance } \\
\text { sheets as pillar } 1 \text { requirements and } \\
\text { Individual Capital Adequacy assessments } \\
\text { as a pillar } 2 \text { requirement. These have } \\
\text { helped to gain a more risk-sensitive } \\
\text { capital level in the industry ahead of the } \\
\text { implementation of Solvency II. } \\
\text { In paving the way for the implementation } \\
\text { of Solvency II, the FSA has been working } \\
\text { over the last } 18 \text { months with a large team } \\
\text { of experts and a substantial budget. The } \\
\text { implementation schedule is on target for } \\
2013 \text { and will result in a fully risk- } \\
\text { sensitive and robust solvency regime for } \\
\text { the United Kingdom, which is expected to } \\
\text { lead to full observance of this principle. }\end{array}$ \\
\hline ICP 24-Intermediaries & $\begin{array}{l}\text { Through the FSMA and the } \\
\text { implementation of Insurance Mediation } \\
\text { Directive, the FSA authorizes and } \\
\text { supervises insurance intermediaries. } \\
\text { There are comprehensive and adequate } \\
\text { financial resources, competency, systems } \\
\text { and controls, client money handling, and } \\
\text { customer disclosure requirements placed } \\
\text { on intermediaries. Supervision is mostly } \\
\text { offsite for smaller intermediaries, but on- } \\
\text { site supervision does occur for the larger } \\
\text { intermediary firms and through thematic } \\
\text { reviews for some smaller intermediaries. } \\
\text { The FSA actively used fines, censures, } \\
\text { and cancellation of authorizations where } \\
\text { needed and to convey what is } \\
\text { unacceptable practices. The FSA's Retail } \\
\text { Distribution Review to address many } \\
\text { persistent problems observed in the retail } \\
\text { investment market is a strong example of } \\
\text { active regulation by the FSA to protect } \\
\text { consumers. It will result in increased } \\
\text { requirements on insurance } \\
\text { intermediaries, which will be more } \\
\text { onerous than those in most other } \\
\text { countries. }\end{array}$ \\
\hline ICP 25-Consumer protection & International best practice \\
\hline $\begin{array}{l}\text { ICP 26-Information, disclosure and transparency } \\
\text { toward markets }\end{array}$ & $\begin{array}{l}\text { The published standard return information } \\
\text { has not been comprehensively revised for } \\
\text { a number of years, even though it has } \\
\text { been updated and improved. This is }\end{array}$ \\
\hline
\end{tabular}




\begin{tabular}{|c|c|}
\hline Insurance Core Principle & Comments \\
\hline & $\begin{array}{l}\text { predominantly because EU developments } \\
\text { on Solvency II have been ongoing for a } \\
\text { few years and it was clear that, when } \\
\text { introduced, they would significantly } \\
\text { change and increase the data that } \\
\text { insurers would be required to disclose. } \\
\text { The FSA, as a response to its urgent } \\
\text { need to acquire a more realistic view of } \\
\text { the firms' financial position in the complex } \\
\text { market it operates, introduced ICAS along } \\
\text { with enhanced capital and reporting } \\
\text { requirements in } 2004 \text {. While, enhanced } \\
\text { capital requirements for long-term } \\
\text { business and realistic balance sheets for } \\
\text { large with-profit insurers have been made } \\
\text { public, additional valuable knowledge of } \\
\text { the financial position from insurers' } \\
\text { individual capital assessments under } \\
\text { ICAS has not had to be made public. } \\
\text { The modern and risk-sensitive capital } \\
\text { requirements set out in Solvency II should } \\
\text { be made public to provide a more } \\
\text { appropriate view of the firms than is } \\
\text { currently in possible in the enhanced } \\
\text { Solvency I. }\end{array}$ \\
\hline ICP 27-Fraud & $\begin{array}{l}\text { The regulation explicitly requires the FSA } \\
\text { to take an active role in combating } \\
\text { insurance fraud and the FSA has acted } \\
\text { accordingly. } \\
\text { Several thematic work projects covering } \\
\text { fraud have been carried out. } \\
\text { Also, the industry is actively engaged in } \\
\text { combating fraud, detecting claim forms, } \\
\text { and monitoring cash transactions for } \\
\text { cash-fraudulent schemes. } \\
\text { Close cooperation and information } \\
\text { exchange with enforcement agencies and } \\
\text { other supervisors, both locally and } \\
\text { internationally, to address fraud to } \\
\text { preserve the integrity of the insurance } \\
\text { sector are practiced by the FSA. } \\
\text { Substantial fines have been imposed, } \\
\text { prompting the whole industry to } \\
\text { implement corrective action. }\end{array}$ \\
\hline $\begin{array}{l}\text { ICP 28-Anti-money-laundering, combating the } \\
\text { financing of terrorism }\end{array}$ & $\begin{array}{l}\text { The AML/CFT requirements applicable to } \\
\text { insurers are broadly in line with the FATF }\end{array}$ \\
\hline
\end{tabular}




\begin{tabular}{|l|l|}
\hline \multicolumn{1}{|c|}{ Insurance Core Principle } & \multicolumn{1}{|c|}{ Comments } \\
\hline & $\begin{array}{l}\text { recommendations. } \\
\text { While the supervisory system was } \\
\text { generally comprehensive for the larger } \\
\text { (“high impact" firms), there was less- } \\
\text { adequate supervision for smaller firms. In } \\
\text { these cases, the risk assessment and } \\
\text { resulting level of supervision often relied } \\
\text { too heavily on the size of the financial } \\
\text { institutions and did not always adequately } \\
\text { take AML/CFT risk into account. }\end{array}$ \\
$\begin{array}{l}\text { The AML regulations require that financial } \\
\text { institutions must require their branches } \\
\text { and subsidiaries, which are located in a } \\
\text { non-EEA state, to apply to the extent } \\
\text { permitted by the law of that state, } \\
\text { measures at least equivalent to those set } \\
\text { out in the AML regulations with regard to } \\
\text { customer due diligence measures, } \\
\text { ongoing monitoring and record-keeping. } \\
\text { However, no evidence of supervisory } \\
\text { work on the compliance of this } \\
\text { requirement was presented. }\end{array}$ \\
\hline
\end{tabular}

\section{Table 4. The United Kingdom: Recommended Action Plan to Improve Observance of the Insurance Core Principles}

\begin{tabular}{|l|l|}
\hline \multicolumn{1}{|c|}{ Principle } & \multicolumn{1}{|c|}{ Recommended Action } \\
\hline ICP 2 & $\begin{array}{l}\text { There is a lack of clarity around how the "desirability to maintain } \\
\text { the competitive advantage of the United Kingdom" and how "the } \\
\text { need to minimize the effects on competition" are supposed to } \\
\text { be taken into account when maintaining market confidence. } \\
\text { This could result in compromising or slowing down prudential } \\
\text { action, although we have seen no evidence to suggest that this } \\
\text { has been a material problem in practice. Clarifying that market } \\
\text { confidence (which is meant to be essentially financial } \\
\text { soundness) and financial stability and consumer protection are } \\
\text { the primary prudential objectives with financial innovation and } \\
\text { competition having secondary applicability (and applying } \\
\text { essentially to rule making and not supervision) would help } \\
\text { significantly in achieving the correct culture within a prudential } \\
\text { regulator. Clarity on the role of the consumer protection } \\
\text { objective in the context of prudential regulation would help } \\
\text { significantly in judging the performance of the prudential } \\
\text { regulator. }\end{array}$ \\
\hline
\end{tabular}




\begin{tabular}{|c|c|}
\hline Principle & Recommended Action \\
\hline ICP 3 & $\begin{array}{l}\text { After a period when staff numbers and expertise increased } \\
\text { substantially, some senior insurance staff are leaving and there } \\
\text { is a considerable risk that the vacuum thus created will only } \\
\text { exacerbate the uncertainty, resulting in more staff losses. } \\
\text { Consideration should be given to strengthening the effort to } \\
\text { retain expertise. } \\
\text { Consider requiring the circumstances in which the chairman or } \\
\text { other Board members of the FSA are removed from office to be } \\
\text { made public. }\end{array}$ \\
\hline ICP 5 & $\begin{array}{l}\text { Formalize the requirement for the FSA to consult with other } \\
\text { home (or host) supervisors before taking action. The } \\
\text { information sharing or consultation should not depend on the } \\
\text { relationship with the incumbent supervisor and/or } \\
\text { circumstances. }\end{array}$ \\
\hline ICP 6,7 and 8 & $\begin{array}{l}\text { Due regard should be given to maintaining the high standards } \\
\text { of the currently centralized activities like licensing, fit-and- } \\
\text { proper assessments, changes in control, and fraud detection, } \\
\text { when restructuring the supervisory authority. }\end{array}$ \\
\hline ICP 11 & $\begin{array}{l}\text { Shortening the time to "market" of the Insurance Sector Team's } \\
\text { reports should be considered. }\end{array}$ \\
\hline ICP 12 & $\begin{array}{l}\text { The FSA should continue to contribute to the finalization of } \\
\text { Solvency II data requirements and work now to position itself } \\
\text { and its insurers for effective and timely implementation of these } \\
\text { data requirements. Shorter lodgment times for data should be } \\
\text { considered. }\end{array}$ \\
\hline ICP 13 & $\begin{array}{l}\text { The CPPI needs to be continued so as to embed the } \\
\text { supervisory analysis and thinking it entails into the processes } \\
\text { and expertise of the FSA. It should be extended to a wider } \\
\text { range of insurers, but this will need careful adjustment, to } \\
\text { ensure the CPPI is applied proportionately to firms of various } \\
\text { impacts, especially in respect of the key financial risks and } \\
\text { associated 'deep dives' when applied to general insurers. It will } \\
\text { clearly involve extra resources. } \\
\text { The FSA should ensure that it continues to conduct random } \\
\text { 'transaction examinations' (in relevant areas such as } \\
\text { underwriting, reinsurance, claims, and even investments) on } \\
\text { both the largest insurers and even some smaller insurers on a } \\
\text { more random basis as an effective complement to top-down } \\
\text { driven examinations in identifying risks. }\end{array}$ \\
\hline ICP 15 & $\begin{array}{l}\text { Consider providing the FSA with the power to arrange for a } \\
\text { compulsory transfer of the obligations under the policies from a } \\
\text { failing insurer to another willing insurer. }\end{array}$ \\
\hline
\end{tabular}




\begin{tabular}{|l|l|}
\hline \multicolumn{1}{|c|}{ Principle } & \multicolumn{1}{|c|}{ Recommended Action } \\
\hline ICP 17 & $\begin{array}{l}\text { Consider including the regulation on holding companies of } \\
\text { insurance groups in the regulatory framework to provide more } \\
\text { supervisory authority over them. }\end{array}$ \\
\hline ICP 19 & $\begin{array}{l}\text { The authorities should maintain the momentum and focus on } \\
\text { the actuarial and supervisory-intensive activity to assess the } \\
\text { adequacy of insurance risk's proper management by insurers } \\
\text { and compliance with this principle. }\end{array}$ \\
\hline ICP 20 & $\begin{array}{l}\text { Adequacy of liabilities for insurance business needs the opinion } \\
\text { of a qualified actuary. This requirement should be extended to } \\
\text { the Gl liabilities. }\end{array}$ \\
\hline ICP 23 & $\begin{array}{l}\text { The excellent focus and quality of resources dedicated to the } \\
\text { Solvency II work needs to continue. The approval of internal } \\
\text { models is a crucial step for the insurance industry in this highly } \\
\text { specialized and sophisticated market. The models will be } \\
\text { complex and only sufficient resources and expertise will allow } \\
\text { understanding of the sufficiency of the resulting capital levels to } \\
\text { warrant a solvent industry. }\end{array}$ \\
\hline ICP 26 & $\begin{array}{l}\text { The modern and risk-sensitive capital requirements in Solvency } \\
\text { II should be made public to provide a more appropriate view of } \\
\text { the firms than the current enhanced Solvency I metrics. }\end{array}$ \\
\hline ICP 28 & $\begin{array}{l}\text { Improve the risk assessment to avoid relying too heavily on the } \\
\text { size of the financial institutions and to take AML/CFT risk } \\
\text { adequately into account. }\end{array}$ \\
\hline
\end{tabular}

\section{J. Authorities Response}

62. The U.K. authorities welcome the IMF's review of the U.K.'s supervisory and regulatory framework for the insurance sector. The assessment came at an important time for the United Kingdom, as the transition to a new regulatory structure begins, and the authorities appreciate this opportunity to comment on the review.

\section{The IMF's assessment recognizes that the U.K.'s supervisory framework already} demonstrates a high level of compliance with the IAIS CPs. Following market turbulence in 2003-04, the FSA strengthened regulation and supervision of the U.K. insurance sector. The review highlights how the FSA has built on those earlier reforms by further increasing the intensity and quality of insurance supervision through many high quality initiatives. The U.K. authorities recognize that there is some way to go to fully implement these new reforms, and agrees with the IMF's conclusion that continuing effective implementation of the programs will further improve the U.K.'s compliance with the CPs.

64. On the 'onsite inspection' $\mathrm{CP}$, the IMF recommends that the new supervisory approach should be proportionately extended to a wider range of insurers and to increase the frequency and number of random 'transaction examinations'. The U.K. 
authorities will consider these recommendations very carefully in the design of the operating model for the Prudential Regulation Authority (PRA) and Financial Conduct Authority (FCA). However, given that the IMF has welcomed the considerable progress that has already been made on this principle, the authorities believe that the FSA is closer to compliance than the IMF has concluded.

65. The assessment also noted the FSA's advanced status in the preparation for implementation of Solvency II, highlighting the "excellent focus and quality of resource" dedicated to this directive. The U.K. authorities will as required implement maximum harmonization of the directive. Therefore all recommendations that are captured by Solvency II will be adopted and any recommendations which are inconsistent with Solvency II will need to be addressed at an European level.

66. Finally, the authorities wish to express their strong support for the role the FSAP plays in promoting the soundness of global financial systems. The authorities want the PRA and the FCA to be compliant with international supervisory standards and look forward to a continuing dialogue with the IMF and other global counterparts to seek to improve the stability and effective supervision of the global financial system.

\section{IOSCO OBJeCtives ANd Principles of SeCURities Regulation ${ }^{4}$}

\section{A. Background}

67. The financial sector is regulated by the U.K. FSA, an integrated regulator with responsibility for regulation and supervision of the full range of financial services. There are 26, 270 regulated firms in the United Kingdom, including 2,059 authorized as investment firms, investment managers, or investment advisors.

68. The U.K. securities markets are very large. The United Kingdom is the leading equity marketplace in Europe as well as an important listing center for foreign equity issuers. At end-September 2010, it had 1,101 U.K. companies and 328 foreign companies listed on its main market, and 1,204 companies (including 224 foreign companies) admitted to its AIM market for small and medium-sized enterprises. As of September 30, U.K.-listed companies had a market value of $£ 1.82$ trillion and the AIM companies (United Kingdom and foreign) of $£ 65.6$ billion.

69. The over-the-counter fixed income and derivative markets in the United Kingdom are large and global in nature. London is an important center for

\footnotetext{
${ }^{4}$ The assessment was carried out using the 2003 International Organization of Securities Commissions (IOSCO) Methodology (the Methodology) for assessing IOSCO Principles. The assessment was undertaken by Shane Tregillis of the Australian Securities and Investments Commission, acting in his personal capacity, and Jennifer Elliott, IMF.
} 
issuance and trading of international sovereign bonds; 30 percent of the $\$ 2.4$ trillion in bonds issued in 2009 were issued in London, with 70 percent of total turnover in the international market taking place in London, mainly in the over-the-counter (OTC) market. ${ }^{5}$ The London Exchange is a leading platform for on-exchange bond trading, trading $£ 4.7$ trillion in bonds during $2010 .^{6}$

70. London hosts several important on-exchange derivatives markets. These include NYSE-LIFFE trading key financial and agricultural futures and options; ICE Futures Europe, which supports the market for several key oil and gas futures as well as clearing for over-thecounter trading in credit default swaps (CDS) and other derivatives; and the London Metal Exchange, which trades futures and options on metals.

71. The United Kingdom has a large asset management market. Funds under management (for U.K. domiciled funds) reached $£ 577.6$ billion in December 2010, with total funds under management in the United Kingdom of $£ 3.9$ trillion. ${ }^{7}$ The United Kingdom is widely recognized as a center for alternative asset management (including hedge funds). There are 450 registered hedge fund managers in the United Kingdom, managing $£ 450$ billion in assets (although this does not include the offshore domiciled assets that may also be managed from London). ${ }^{8}$ Exchange-traded funds (ETFs) are a rapidly growing asset class in the United Kingdom.

\section{B. Financial Services Authority Approach to Supervision}

\section{The FSA undertakes risk-based supervision and has evolved a structured}

approach to supervision. Particular lines of business or activities are then measured against the risk dashboard to determine a firm's particular risk profile. Every firm is given an impact measure showing the potential harm to the FSA objectives if it fails or if the risks crystallize. This is a proxy for its regulatory footprint or size. The impact metrics used to calculate the firm's impact measures differ depending on the sector within which it operates. The risk profile is then used to categorize firms for the type of supervision they will receive. Highimpact firms will receive what is called "close and continuous" supervision, with a dedicated relationship manager and team, including more than one supervisor and a manager. A medium-high impact firm may have a smaller team but still be in close and continuous contact. A medium-low to medium-high firm would be "relationship managed," meaning that

\footnotetext{
${ }^{5}$ International Financial Services London, 2009 Bond Market Report.

${ }^{6}$ FSA data.

7 Investment Management Association estimate "Asset Management in the U.K. 2009-2010-The IMA Annual Survey,” July 2010 http://www.investmentfunds.org.U.K./research/ima-annual-industry-survey.

${ }^{8}$ Alternative Investment Managers Association, 2009 Hedge Fund Report.
} 
it is directly supervised on a day-to-day basis, but may be part of a group of firms supervised with a less-intensive cycle of consultations. A low-impact firm will be categorized as a "small firm" and not "relationship managed"; it would then be put into a very large pool of $(16,000)$ firms handled by the small-firms group.

\section{Those firms that are relationship-managed are subject to an ARROW}

assessment. Medium-low firms are subject to an ARROW light assessment that focuses on core areas. The ARROW determines the risk issues to be monitored by the FSA and includes a review of the firm's business model, oversight, and governance structures and operational controls.

74. Small firms are not subject to an ARROW review. Small firms are, however, profiled; their reporting, along with other factors (such as complaints received, type of activity, market intelligence), is used to generate a risk profile that identifies those small firms that require additional supervision. For example, the largest fund manager in the smallfirm category has $£ 10.8$ billion of funds under management, with a market share of .043 percent.

75. The FSA supplements this risk-based formula with thematic reviews. It undertakes special inspections of samples of firms on various topics. For example, the FSA has conducted reviews of 'spread betting' firms to ensure internal controls are sufficient; it has also done a number of reviews looking at handling of client monies. Thematic reviews can apply to any firm.

\section{Assessment Challenges}

76. The IOSCO Methodology clearly requires that the assessment be made at the "point of time" of the mission. In the current environment, given the state of dynamic flux, this poses both practical and methodological challenges. Specifically, there are three profound forces at play (i) the post-crisis response of the FSA itself and the changes it is introducing in its supervisory philosophy and approach — as the FSA itself has noted, this is very much a work in progress; (ii) U.K. regulatory reform; and (iii) the changes to the regulatory structure in Europe as of January this year and the current heavy load of EU regulatory proposals. The assessors acknowledge that the task of a "point in time" assessment is a difficult one.

77. The assessors have noted, where appropriate, future considerations in reference to these ongoing changes. A key challenge is the uncertainty, given the proposed new regulatory structure in the United Kingdom, and the potential impact this may have on the FSA. The FSA's supervisory approach relies on the skills and judgment of its experienced supervisors. If there were to be a significant loss of supervisory skills and experience in the FSA for any reason, this would call into question the resilience of the current assessment against the IOSCO Principles. Accordingly, this assessment report will need to be read in the future alongside a careful review of how the transitional arrangements unfold in the coming 
period. As noted below, the assessors consider that, while the FSA is taking active steps to manage the transition, there remain considerable risks over the next few years as a result of this uncertainty.

\section{Preconditions for Effective Securities Regulation}

78. The preconditions for effective supervision appear to be in place in the United Kingdom. These preconditions include a stable macroeconomic environment, a sound legal and accounting framework, and the effectiveness of procedures for the efficient resolution of problems in the securities market.

\section{E. Main Findings}

79. General: The methodology requires assessors to give a rating at the current point in time. However, given the state of flux in the United Kingdom at this moment, an analysis would be incomplete without some evaluation of the direction in which the system is heading. An earlier proposal for the regulatory reform included a recommendation to move the regulation of issuers to a government department and to possibly move the FSA enforcement function to a public prosecution agency. The decision was made to keep markets intact within the FCA by keeping the United Kingdom Listing Authority (UKLA) with markets regulation and moving enforcement into the FCA rather than to split it off into a separate agency. In addition, the regulators' ability to use criminal sanctions when appropriate is a positive trend.

80. We also consider the new programs, such as the increased focus on client assets, a positive development. This and other works in progress need to be continued and carried over as a core part of the capabilities and program of the FCA. In addition, the efforts by the FSA Board and senior management to put in place transitional structures as soon as possible are important initiatives to create some certainty for the staff and market participants, given the length of transition involved.

81. The key risk to the system is uncertainty — a risk identified widely by market participants and by the Board and senior management of the FSA. The sheer scale of the changes creates significant risks. In particular, the fundamental revamp in the structure of U.K. regulation, and the very full European agenda coming on top of the current demanding internal supervisory enhancement program will inevitably create uncertainty and distraction, with a potential impact on staff retention and attraction along with resource pressures. These constitute material downside risks going forward.

82. Principles 1-5, Principles relating to the regulator: The FSA operates as an independent regulator with a broad remit covering all aspects of securities markets. It has the ability to act independently and has sufficient control over its budget. The structure and governance of the FSA are broadly in line with international standards. There is some lack of clarity in the mandate of the organization, which led to a less than optimal balancing of 
objectives leading up to the crisis. In crafting the new mandate for the FCA, the authorities should clearly set out investor protection, fair markets, and financial stability as the key objectives of the organization. Resources are broadly in place, but the allocation of resources across mid-sized firms is insufficient and, given the demands of an increased regulatory and policy agenda and a transition to a new structure, there is considerable concern that resources will be unduly constrained in the near future. The legislation does not protect the chief executive, Chairman or Board of Directors from removal without cause and this should be rectified in the FCA legislation.

83. Principles 6-7, Principles relating to self-regulation: Self-regulation is not widely used in the United Kingdom. The recognized investment exchanges and the recognized clearinghouses carry out some regulatory functions, chiefly market surveillance. The reliance on trading platform operators appears to be well-founded; there are good communications systems in place between the FSA and the market operators; and the FSA has an adequate oversight program in place.

84. Principles 8-10, Principles relating to enforcement of securities regulation: The FSA has broad powers to inspect and investigate regulated entities and, in the case of market abuse, unregulated parties. The FSA can apply administrative sanctions and has the authority to bring criminal proceedings. It can apply to a court for various civil remedies including restitution. The FSA has put in place an enhanced enforcement program, beginning in 2007, and this appears to have yielded results in creating a more credible deterrence to improper behavior. The FSA has also devoted significantly greater resources to enforcement since 2007. A number of successful cases have been brought with very high fines, including some criminal convictions for insider dealing. The supervision program is well-founded and appears adequate for those firms that are identified as requiring close and continuous supervision. It is not clear, however, that sufficient attention is being paid to mid-sized firms (across all securities related activities) and, further, there is a greater need to implement "bottom-up" analysis of firm operations using on-site examinations to supplement the "topdown" risk analysis. While many good supervisory initiatives have been put in place, such as the core conduct program, these are still taking hold.

85. Principles 11-13, Principles for cooperation in regulation: The FSA has the ability and capacity to share information and cooperate with regulators, both domestically and internationally. It can share confidential information with any EEA member country without the need for an MOU and with other countries through an MOU. It is a signatory to the IOSCO MMOU and the Committee of European Securities Regulators (CESR) MMOU.

86. Principles 14-16, Principles for Issuers: The FSA has fully implemented the prospectus, market abuse, and Markets in Financial Instruments Directive (MiFID) through its rules for issuers. Requirements are in place for offering and disclosure documents. The UKLA, which is part of the FSA, has a full program of review of prospectuses and 
continuous obligations. Accounting and auditing standards are in place and auditors are subject to oversight and independence standards.

87. Principles 17-20, Principles for collective investment schemes: The framework for collective investment schemes is compliant with the Principles. Investment managers, even those operating funds exempt from regulation, such as hedge funds, are subject to authorization and reporting requirements. All retail funds and Undertakings for the Collective Investment of Transferable Securities (UCITS) must register with the FSA (other than nonU.K. UCITS, which must notify the FSA). Funds must be established as unit trusts or corporations, with assets segregated from those of the manager. Custodians must be independent of the investment manager and funds are subject to valuation, pricing, and redemption standards. The supervision of investment managers could be enhanced, as expressed in the comments on Principle 10.

88. Principles 21-24, Principles for market intermediaries: The framework for licensing and ongoing requirements for market intermediaries is in place. The FSA uses a structured, risk-based approach to intermediary supervision, which brings a highly consistent and well-thought-out approach to applying constrained resources to a very large regulated population. The coverage, intensity, and effectiveness of supervision required by the Principles are, however, not fully in place. Greater attention to mid-sized firms, together with a slight rebalancing of the approach to include some "bottom-up" assessment of firms, using on-site work to supplement the top-down model approach, would enhance the effectiveness of supervision. Further, many supervisory enhancement initiatives are still in progress and the FSA is encouraged to further embed these initiatives into day-to-day supervision. Policies and procedures should be put in place for the handling of failing firms and consideration should be given to intensifying the supervision of firms, including through greater use of onsite inspections. All firms should be required to seek a third-party review of internal controls (for example, through an audit).

89. Principles 25-30, Principles for the Secondary Markets: There is a full program of authorization and supervision of trading systems and markets. There are robust market surveillance systems and processes in place and transaction reporting systems that encompass a significant portion of transactions completed in the United Kingdom (including designated OTC markets and organized markets). Trading systems rules and new products are reviewed by the FSA. Fragmentation of markets has led to an erosion of transparency in markets, a matter that has been identified and is being addressed in the current review of market structure under the MiFID. 


\section{Table 5. United Kingdom: Summary Implementation of the IOSCO Principles- Detailed Assessments}

\begin{tabular}{|c|c|}
\hline Principles & Findings \\
\hline $\begin{array}{l}\text { Principle } 1 . \text { The responsibilities of the regulator } \\
\text { should be clearly and objectively stated }\end{array}$ & $\begin{array}{l}\text { The mandate for the future FCA should } \\
\text { ensure that objectives are set in such a way } \\
\text { as to ensure that the primary supervisory } \\
\text { outcomes for which the agency is } \\
\text { responsible are clear. }\end{array}$ \\
\hline $\begin{array}{l}\text { Principle } 2 \text {. The regulator should be operationally } \\
\text { independent and accountable in the exercise of its } \\
\text { functions and powers }\end{array}$ & $\begin{array}{l}\text { The FSA operates independently on a day- } \\
\text { to-day basis and has adequate control over } \\
\text { its budget. Legislation should be amended } \\
\text { to protect against removal of the Chief } \\
\text { Executive, Chairman and Board of Directors } \\
\text { without cause. }\end{array}$ \\
\hline $\begin{array}{l}\text { Principle 3. The regulator should have adequate } \\
\text { powers, proper resources and the capacity to } \\
\text { perform its functions and exercise its powers }\end{array}$ & $\begin{array}{l}\text { The FSA has broad authority to carry out its } \\
\text { mandate and currently retains the capacity } \\
\text { to do so. Resources appear/are likely to be } \\
\text { strained by the current regulatory agenda } \\
\text { and transitional environment, creating a real } \\
\text { risk of capacity erosion. }\end{array}$ \\
\hline $\begin{array}{l}\text { Principle } 4 \text {. The regulator should adopt clear and } \\
\text { consistent regulatory processes }\end{array}$ & $\begin{array}{l}\text { The FSA has strong systems in place to } \\
\text { ensure consistency of its work and it } \\
\text { operates with a high degree of } \\
\text { transparency. }\end{array}$ \\
\hline $\begin{array}{l}\text { Principle } 5 \text {. The staff of the regulator should } \\
\text { observe the highest professional standards }\end{array}$ & $\begin{array}{l}\text { The FSA staff is subject to high-quality } \\
\text { professional standards. }\end{array}$ \\
\hline $\begin{array}{l}\text { Principle } 6 \text {. The regulatory regime should make } \\
\text { appropriate use of self-regulatory organizations } \\
\text { (SROs) that exercise some direct oversight } \\
\text { responsibility for their respective areas of } \\
\text { competence and to the extent appropriate to the } \\
\text { size and complexity of the markets }\end{array}$ & $\begin{array}{l}\text { The regulatory system relies on market } \\
\text { operators and clearinghouses for frontline } \\
\text { surveillance of the markets. This limited use } \\
\text { of a self-regulatory function appears to work } \\
\text { well. This Principle is descriptive and has no } \\
\text { criteria; it is therefore "not assessed." }\end{array}$ \\
\hline $\begin{array}{l}\text { Principle 7. SROs should be subject to the } \\
\text { oversight of the regulator and should observe } \\
\text { standards of fairness and confidentiality when } \\
\text { exercising powers and delegated responsibilities }\end{array}$ & $\begin{array}{l}\text { The trading platforms and clearinghouses } \\
\text { are subject to a robust oversight regime. } \\
\text { Rules and products are subject to regulatory } \\
\text { review and on-site examinations are } \\
\text { undertaken. }\end{array}$ \\
\hline $\begin{array}{l}\text { Principle } 8 \text {. The regulator should have } \\
\text { comprehensive inspection, investigation and } \\
\text { surveillance powers }\end{array}$ & $\begin{array}{l}\text { The FSA has the powers to carry out } \\
\text { inspections, investigations, and surveillance } \\
\text { of the markets. }\end{array}$ \\
\hline $\begin{array}{l}\text { Principle 9. The regulator should have } \\
\text { comprehensive enforcement powers }\end{array}$ & $\begin{array}{l}\text { The FSA has the powers to take } \\
\text { enforcement actions, including the ability to } \\
\text { bring administrative and criminal } \\
\text { proceedings. It can apply to a court for civil } \\
\text { remedies such as restitution. It is able to } \\
\text { levy penalties that are both flexible and } \\
\text { large enough to create credible deterrence. }\end{array}$ \\
\hline $\begin{array}{l}\text { Principle 10.The regulatory system should ensure } \\
\text { an effective and credible use of inspection, } \\
\text { investigation, surveillance and enforcement }\end{array}$ & $\begin{array}{l}\text { The FSA has enhanced its enforcement } \\
\text { program, both in terms of approach and } \\
\text { resources, over the past several years and }\end{array}$ \\
\hline
\end{tabular}




\begin{tabular}{|c|c|}
\hline Principles & Findings \\
\hline $\begin{array}{l}\text { powers and implementation of an effective } \\
\text { compliance program. }\end{array}$ & $\begin{array}{l}\text { this enhancement has begun to show good } \\
\text { early results. The challenge will be to } \\
\text { sustain and build on these efforts. There is } \\
\text { a need to enhance current supervision of } \\
\text { intermediaries by supplementing the current } \\
\text { top-down risk-based model with a greater } \\
\text { degree of "bottom-up" testing through the } \\
\text { use of on-site inspections and verification } \\
\text { on a risk basis for a wider range of } \\
\text { intermediaries. The current supervisory } \\
\text { enhancements are important and } \\
\text { necessary, but many are at an early stage } \\
\text { and very much a work-in-progress. }\end{array}$ \\
\hline $\begin{array}{l}\text { Principle } 11 \text {. The regulator should have the } \\
\text { authority to share both public and nonpublic } \\
\text { information with domestic and foreign counterparts }\end{array}$ & $\begin{array}{l}\text { The FSA has full authority to share } \\
\text { information with foreign and domestic } \\
\text { counterparts, provided appropriate } \\
\text { protections are in place. }\end{array}$ \\
\hline $\begin{array}{l}\text { Principle 12. Regulators should establish } \\
\text { information sharing mechanisms that set out when } \\
\text { and how they will share both public and nonpublic } \\
\text { information with their domestic and foreign } \\
\text { counterparts }\end{array}$ & $\begin{array}{l}\text { The FSA is a signatory to the IOSCO } \\
\text { MMOU and the CESR MMOU and a } \\
\text { number of bilateral MOUs. It receives and } \\
\text { responds to a high volume of requests from } \\
\text { foreign regulators. }\end{array}$ \\
\hline $\begin{array}{l}\text { Principle 13. The regulatory system should allow } \\
\text { for assistance to be provided to foreign regulators } \\
\text { who need to make inquiries in the discharge of } \\
\text { their functions and exercise of their powers }\end{array}$ & $\begin{array}{l}\text { The FSA is able to provide foreign } \\
\text { regulators with assistance in an } \\
\text { investigation and has demonstrated its } \\
\text { willingness and ability to do so. }\end{array}$ \\
\hline $\begin{array}{l}\text { Principle 14. There should be full, timely and } \\
\text { accurate disclosure of financial results and other } \\
\text { information that is material to investors' decisions }\end{array}$ & $\begin{array}{l}\text { Issuers are subject to a full range of } \\
\text { disclosure requirements, including } \\
\text { prospectus and continuing disclosure } \\
\text { obligations. The UKLA, as part of the FSA, } \\
\text { actively undertakes review of disclosure } \\
\text { documentation and monitors ongoing } \\
\text { disclosure by companies. }\end{array}$ \\
\hline $\begin{array}{l}\text { Principle } 15 \text {. Holders of securities in a company } \\
\text { should be treated in a fair and equitable manner }\end{array}$ & $\begin{array}{l}\text { Shareholder protections are in place, } \\
\text { including voting and notice rights, } \\
\text { transaction reporting requirements, and } \\
\text { disclosure of insider transactions. Takeover } \\
\text { rules are subject to controls administered by } \\
\text { the Takeover Panel. Related-party } \\
\text { transactions are subject to disclosure and } \\
\text { shareholder voting requirements for } \\
\text { premium listed companies. }\end{array}$ \\
\hline $\begin{array}{l}\text { Principle } 16 \text {. Accounting and auditing standards } \\
\text { should be of a high and internationally acceptable } \\
\text { quality }\end{array}$ & $\begin{array}{l}\text { Accounting and auditing standards meet } \\
\text { international standards. Auditors are subject } \\
\text { to independence, oversight, and disciplinary } \\
\text { measures. }\end{array}$ \\
\hline $\begin{array}{l}\text { Principle } 17 \text {. The regulatory system should set } \\
\text { standards for the eligibility and the regulation of } \\
\text { those who wish to market or operate a collective } \\
\text { investment scheme }\end{array}$ & $\begin{array}{l}\text { Comprehensive requirements are in place } \\
\text { for the authorization of investment } \\
\text { managers and the registration of funds. As } \\
\text { with intermediaries in other categories, } \\
\text { wider use of onsite inspections would } \\
\text { enhance oversight of investment managers. }\end{array}$ \\
\hline $\begin{array}{l}\text { Principle } 18 . \text { The regulatory system should provide } \\
\text { for rules governing the legal form and structure of }\end{array}$ & $\begin{array}{l}\text { Investment funds must be unit trusts or } \\
\text { corporations. There are rules in place for }\end{array}$ \\
\hline
\end{tabular}




\begin{tabular}{|c|c|}
\hline Principles & Findings \\
\hline $\begin{array}{l}\text { collective investment schemes and the } \\
\text { segregation and protection of client assets }\end{array}$ & $\begin{array}{l}\text { the safekeeping and segregation of client } \\
\text { assets, including a requirement for an } \\
\text { independent custodian. }\end{array}$ \\
\hline $\begin{array}{l}\text { Principle 19. Regulation should require disclosure, } \\
\text { as set forth under the principles for issuers, which } \\
\text { is necessary to evaluate the suitability of a } \\
\text { collective investment scheme for a particular } \\
\text { investor and the value of the investor's interest in } \\
\text { the scheme }\end{array}$ & $\begin{array}{l}\text { Collective investment scheme managers } \\
\text { are required to make a full range of } \\
\text { disclosure to fund investors. Investors are } \\
\text { entitled to an initial prospectus and annual } \\
\text { reports. }\end{array}$ \\
\hline $\begin{array}{l}\text { Principle } 20 . \text { Regulation should ensure that there } \\
\text { is a proper and disclosed basis for assets } \\
\text { valuation and the pricing and the redemption of } \\
\text { units in a collective investment scheme }\end{array}$ & $\begin{array}{l}\text { There are rules in place governing pricing, } \\
\text { valuation, and redemption; and these must } \\
\text { be disclosed in the fund prospectus. }\end{array}$ \\
\hline $\begin{array}{l}\text { Principle } 21 . \text { Regulation should provide for } \\
\text { minimum entry standards for market intermediaries }\end{array}$ & $\begin{array}{l}\text { There is a full set of authorization } \\
\text { requirements applicable to different } \\
\text { business activities. The process of } \\
\text { authorization is systematic and organized, } \\
\text { which is important, given the high number of } \\
\text { authorized persons. There is a need to } \\
\text { enhance supervision of intermediaries by } \\
\text { supplementing the current top-down, risk- } \\
\text { based model with a greater degree of } \\
\text { "bottom-up" testing through on-site } \\
\text { inspections and verification on a risk basis } \\
\text { for a wider range of intermediaries. }\end{array}$ \\
\hline $\begin{array}{l}\text { Principle 22. There should be initial and ongoing } \\
\text { capital and other prudential requirements for } \\
\text { market intermediaries that reflect the risks that the } \\
\text { intermediaries undertake }\end{array}$ & $\begin{array}{l}\text { The FSA Handbook implements the EU } \\
\text { Capital Resources Directive (CRD) and as } \\
\text { such, all large intermediaries or } \\
\text { intermediaries that handle or hold customer } \\
\text { assets or cash are subject to a capital } \\
\text { regime sensitive to the range of risks. Very } \\
\text { small and simple firms are subject to a flat } \\
\text { requirement of six months expenses. All } \\
\text { firms are subject to reporting and } \\
\text { monitoring. All firms that are not purely } \\
\text { advisors should be required to have their } \\
\text { annual financial statements audited by an } \\
\text { independent and qualified auditor. }\end{array}$ \\
\hline $\begin{array}{l}\text { Principle 23. Market intermediaries should be } \\
\text { required to comply with standards for internal } \\
\text { organization and operational conduct that aim to } \\
\text { protect the interests of clients, ensure proper } \\
\text { management of risk, and under which } \\
\text { management of the intermediary accepts primary } \\
\text { responsibility for these matters }\end{array}$ & $\begin{array}{l}\text { The FSA Handbook contains a full range of } \\
\text { internal control, sales, and business } \\
\text { conduct rules. These are reviewed as part } \\
\text { of regular supervision. There is, however, } \\
\text { no requirement for an external review of } \\
\text { internal controls, although auditors are } \\
\text { explicitly required to audit the handling of } \\
\text { client monies. A broader remit for an } \\
\text { auditor's or other independent external } \\
\text { review of internal controls is warranted. }\end{array}$ \\
\hline $\begin{array}{l}\text { Principle 24. There should be a procedure for } \\
\text { dealing with the failure of a market intermediary in } \\
\text { order to minimize damage and loss to investors } \\
\text { and to contain systemic risk }\end{array}$ & $\begin{array}{l}\text { The capital position of firms is being } \\
\text { monitored and supervisors have a range of } \\
\text { tools available to take action against a } \\
\text { failing firm. A firm that falls below required } \\
\text { capital is obliged to immediately report this }\end{array}$ \\
\hline
\end{tabular}




\begin{tabular}{|c|c|}
\hline Principles & Findings \\
\hline & $\begin{array}{l}\text { to the FSA. The FSA can request that the } \\
\text { secretary of state apply to the court for a } \\
\text { liquidator. A formal set of policies and } \\
\text { procedures should be put in place for the } \\
\text { handling of a failing firm, particularly for } \\
\text { firms that are considered low-impact or } \\
\text { small-sized. }\end{array}$ \\
\hline $\begin{array}{l}\text { Principle } 25 \text {. The establishment of trading systems } \\
\text { including securities exchanges should be subject } \\
\text { to regulatory authorization and oversight }\end{array}$ & $\begin{array}{l}\text { Most exchanges and multilateral trading } \\
\text { facilities are subject to high standards for } \\
\text { entry relating to their trading systems, } \\
\text { trading rules, and surveillance systems. }\end{array}$ \\
\hline $\begin{array}{l}\text { Principle } 26 \text {. There should be ongoing regulatory } \\
\text { supervision of exchanges and trading systems, } \\
\text { which should aim to ensure that the integrity of } \\
\text { trading is maintained through fair and equitable } \\
\text { rules that strike an appropriate balance between } \\
\text { the demands of different market participants }\end{array}$ & $\begin{array}{l}\text { Exchanges and multilateral trading facilities } \\
\text { are subject to a full program of continuous } \\
\text { supervision, including on-site reviews, and } \\
\text { reviews of new rules. New products are } \\
\text { reviewed by the FSA. }\end{array}$ \\
\hline $\begin{array}{l}\text { Principle } 27 . \text { Regulation should promote } \\
\text { transparency of trading }\end{array}$ & $\begin{array}{l}\text { All organized markets include pre- and post- } \\
\text { trade requirements. Further, a broad range } \\
\text { of transactions undertaken in the United } \\
\text { Kingdom must be reported ultimately by the } \\
\text { authorized firms to the FSA (including all } \\
\text { trades in securities traded on organized } \\
\text { markets and some designated OTC } \\
\text { markets). The competition fostered by the } \\
\text { MiFID has, however, resulted in multiple } \\
\text { trading venues, and because there is no } \\
\text { European consolidated tape, there is a } \\
\text { fragmentation of post-trade transparency. } \\
\text { This has been recognized and is being } \\
\text { considered in the current MiFID review. }\end{array}$ \\
\hline $\begin{array}{l}\text { Principle 28. Regulation should be designed to } \\
\text { detect and deter manipulation and other unfair } \\
\text { trading practices }\end{array}$ & $\begin{array}{l}\text { The FSA has a robust transaction reporting } \\
\text { system in place. It works in close } \\
\text { cooperation with the market operators, } \\
\text { which have responsibility for real-time } \\
\text { surveillance. There is a well-thought-out } \\
\text { system of detecting, investigating, and } \\
\text { escalating market abuse cases. }\end{array}$ \\
\hline $\begin{array}{l}\text { Principle 29. Regulation should aim to ensure the } \\
\text { proper management of large exposures, default } \\
\text { risk and market disruption }\end{array}$ & $\begin{array}{l}\text { The derivative trading platforms monitor } \\
\text { large positions and all positions are reported } \\
\text { to the FSA, along with a weekly report on } \\
\text { the largest positions in key future contracts. } \\
\text { Large counterparty exposures in firms are } \\
\text { monitored through prudential supervision. }\end{array}$ \\
\hline $\begin{array}{l}\text { Principle } 30 \text {. Systems for clearing and settlement } \\
\text { of securities transactions should be subject to } \\
\text { regulatory oversight, and designed to ensure that } \\
\text { they are fair, effective and efficient and that they } \\
\text { reduce systemic risk }\end{array}$ & $\begin{array}{l}\text { Clearing and settlement systems have been } \\
\text { fully considered under separate } \\
\text { CPSS/IOSCO assessments. }\end{array}$ \\
\hline
\end{tabular}




\section{F. Recommended Action Plan}

\section{Table 6. United Kingdom: Recommended Action Plan to Improve Implementation of the IOSCO Principles}

\begin{tabular}{|c|c|}
\hline Principle & Recommended Action \\
\hline 1 & $\begin{array}{l}\text { Clarify the mandate of the FSA/FCA in order to provide clear guidance } \\
\text { on priorities between potentially competing elements of the mandate (for } \\
\text { example, between market integrity and competitiveness of the U.K. } \\
\text { market). }\end{array}$ \\
\hline 2 & $\begin{array}{l}\text { Legislation should be amended to include clear formal terms that protect } \\
\text { the Chief Executive, Chairman, and Directors of the Board of the } \\
\text { proposed new regulatory authorities from removal other than for cause. }\end{array}$ \\
\hline 3 & $\begin{array}{l}\text { The FSA Board should continue to carefully review whether resources } \\
\text { are sufficient to handle the current regulatory agenda and transition to } \\
\text { the new regulatory authority without adversely impacting core regulation } \\
\text { and supervision activities. A review of the resources for more intensive } \\
\text { on-site inspection of mid-sized firms should be undertaken, and, in } \\
\text { particular, to ensure that the proposed FCA is sufficiently resourced for } \\
\text { firm-level supervision in addition to its more general sector and thematic } \\
\text { work. }\end{array}$ \\
\hline 9 & $\begin{array}{l}\text { Authorities should consider amending the FSMA to allow the FSA to } \\
\text { compel necessary information from any third party, regardless of whether } \\
\text { there is a connection to the person under investigation. }\end{array}$ \\
\hline $10,17,21$ & $\begin{array}{l}\text { Use of on-site inspections should be broadened, both in terms of } \\
\text { coverage of mid-range firms and as a tool to test top-down risk models } \\
\text { using a "bottom-up" approach }\end{array}$ \\
\hline 22 & $\begin{array}{l}\text { Require all firms that are not purely advisory to have annual audits of } \\
\text { financial statements. }\end{array}$ \\
\hline 23 & $\begin{array}{l}\text { A formal requirement should be introduced requiring firms to have } \\
\text { internal controls formally reviewed by an independent third party, with } \\
\text { reporting to the regulator. }\end{array}$ \\
\hline 27 & $\begin{array}{l}\text { The FSA should continue to actively engage through the MiFID review } \\
\text { process to improve market quality and transparency of equity market } \\
\text { trading in a competitive multi-trading venue environment. }\end{array}$ \\
\hline
\end{tabular}

\section{G. Authorities' Response}

90. The U.K. authorities welcome the IMF's review of the U.K.'s supervisory and regulatory framework for the securities markets. The assessment has come at an important time for the United Kingdom, as the transition to a new regulatory structure begins, and the authorities appreciate this opportunity to comment on the review.

\section{The IMF assessment recognizes that the U.K.'s supervisory framework already} demonstrates a very high level of compliance with the IOSCO Principles of Securities 
Regulation and is well placed to manage the challenging task of supervising U.K.'s deep and complex markets and associated activities. In particular, the IMF notes the success of the FSA's enhanced enforcement program, which has delivered a credible deterrence to improper market behavior.

92. The IMF's key recommendation is to increase the intensity of supervision for mid-sized securities firms with greater use of "bottom-up" analysis of firms' operations using on-site examinations to supplement the "top-down" risk analysis. The U.K. authorities will therefore consider these recommendations, and others, very carefully in the design of the operating model for the PRA and FCA.

93. Finally, the authorities wish to express their support for the role the FSAP plays in promoting the soundness of global financial systems. The authorities want the PRA and the FCA to be compliant with international supervisory standards and look forward to a continuing dialogue with the IMF and other global counterparts to seek to improve the stability and effective supervision of the global financial system.

\section{CPSS CORE PRINCIPleS FOR SyStemiCAlly IMPORTANT PAYMENT SySTEMS- CHAPS $^{9}$}

\section{A. Information and Methodology Used for Assessment}

94. This assessment was undertaken in the context of an IMF FSAP exercise for the United Kingdom in January 2011. The assessment covers the Clearing House Automated Payment System (CHAPS), which provides real-time gross settlement (RTGS) for sterling transactions, and the relevant operational services provided by the BoE in support of CHAPS. The CHAPS scheme is managed by CHAPS Clearing Company Limited (CHAPSCo), while payments are processed by the RTGS infrastructure owned and operated by the BoE. ${ }^{10}$

95. The assessors reviewed several previous assessments and held discussions with relevant parties. During the 2002 FSAP, a detailed assessment was made of CHAPS against the Core Principles. More recently, the BoE published an assessment of CHAPS against the Core Principles as an Annex to its 2008 Payments System Oversight Report. A new assessment was prepared by the BoE in 2010, which was not published, and this was updated for the FSAP mission. The BoE also provided a number of documents relevant for the

\footnotetext{
${ }^{9}$ The assessor was Nikil Chande, Principal Researcher in the Department of Financial Stability at Bank of Canada, in collaboration with Christine Sampic, IMF Senior Financial Sector Expert.

10 The BoE 1) settles CHAPS payments through debits and credits to members' settlement accounts held on its books, 2) operates the Enquiry Link which allows members to interact with the RTGS infrastructure, so they can monitor payments progress, manage payments in the centralized queue, and make certain funds transfers, and 3) and provides CHAPS members with collateralized intra-day liquidity to support CHAPS payments.
} 
assessment. Extensive meetings were held with the BoE and CHAPSCo, supplemented by discussions with several CHAPS members and a bank that accesses the system indirectly through a CHAPS member. No obstacles were faced in the work. The authorities and others were fully cooperative.

96. The methodology for the assessment was derived from the Core Principles as well as the IMF and World Bank's Guidance Note for Assessing Observance of Core Principles for Systemically Important Payment Systems.

\section{B. Institutional and Market Structure-Overview}

97. The CHAPS system typically processes large-value payments, but there are no restrictions on the type or value of transactions. In 2009, the average size of payment transferred by the system was $£ 1.76$ million although the average is skewed by a small number of very large payments (approximately 94 per cent of payment value is attributable to 5 per cent of payment volume). Typical payments are large financial transactions, either between banks or between banks and corporations. Some retail transactions such as housing market purchases also go through CHAPS. CHAPS is also used for sterling pay-ins and payouts related to Continuous Linked Settlement (CLS) transactions and for transfers to and from the concentration bank in relation to $\mathrm{LCH}$ margin payments.

\section{Table 7. Statistical Information Regarding CHAPS}

Daily Average Volumes (thousands) and Values of Transactions ( $£$ billions), 2007-10

\begin{tabular}{|c|c|c|c|c|c|c|c|}
\hline \multicolumn{2}{|c|}{2007} & \multicolumn{2}{c|}{2008} & \multicolumn{2}{c|}{2009} & \multicolumn{2}{c|}{2010} \\
\hline Volume & Value & Volume & Value & Volume & Value & Volume & Value \\
\hline 141 & 268 & 136 & 284 & 126 & 235 & 127 & 224 \\
\hline
\end{tabular}

98. CHAPS is a highly tiered payment system. There are 16 direct members of CHAPS as well as the BoE and CLS Bank. In turn, the members act as correspondent banks for other banks, processing payments on their behalf. Payment flows are highly concentrated, with the five most active members accounting for approximately 80 per cent of payment value, and the two most active accounting for half of the total value.

99. Prior to 2008, CHAPSCo operated a separate scheme for processing euro payments, called CHAPS Euro. CHAPS Euro was decommissioned in 2008 following the launch of TARGET2. Previous CHAPS Euro members and their customers now effect their TARGET payments in euro via another country's system, and the BoE makes and receives its euro payments through access to TARGET2 via De Nederlandsche Bank. A liquidity bridge remains between the RTGS infrastructure and TARGET2, which allows CHAPS members to transfer euro payments between their TARGET2 accounts and their CHAPS accounts. This enables euro funds to act as collateral for the provision of intraday liquidity in sterling. 
100. In addition to CHAPS, CHAPSCo manages the Faster Payment Service (FPS), which was launched in May 2008. FPS is a deferred multilateral net settlement system for retail electronic payments in the United Kingdom, which uses the RTGS infrastructure for final settlement during the day. The FPS service accommodates telephone and internet payments of three main types: single immediate, forward-dated, and standing order payments. From January-September 2010, the FPS settled a daily average value of $£ 643$ million and daily average volume of 1.7 million payments.

\section{The CHAPSCo Board usually meets on a quarterly basis, and although the} Board covers both CHAPS and FPS, system specific issues are voted on separately. Each member is entitled to appoint one Director regardless of whether they are active in either one or both of CHAPS and FPS. The BoE attends CHAPSCo Board meetings with "observer status".

\section{CHAPSCo has a contractual relationship with the U.K. Payments Council,} which is the strategic governance body for the U.K. payments industry. ${ }^{11}$ Under the terms of the contract, CHAPSCo has agreed to comply with directions given by the Board of the Payments Council in pursuit of the Council's objectives. These objectives are to deliver innovation; ensure that payment systems are open and accountable; and maintain the integrity of the payment systems. Nonetheless, CHAPSCo remains responsible for the day-to-day management of the CHAPS systems, including risk management.

103. CHAPS is overseen by the BoE. On January 5, 2010, HMT recognized CHAPS as an interbank payment system under Part 5 of the Banking Act 2009, giving the BoE statutory responsibility for overseeing it.

\section{Main Findings}

104. Summary: CHAPS is a safe, reliable and efficient system for transferring largevalue, time-sensitive payments. CHAPS payments benefit from a robust legal environment that ensures settlement finality can occur in real-time. The system has comprehensive features that allow its members to properly manage their liquidity and operational risks. In normal operation, payments do not expose members to credit risk; however, if the system's Bypass mode is needed as a contingency, members can be exposed to credit risk. In the unlikely event that a member in a net debit position were to default while in Bypass mode, there are not clear procedures to set forth how the losses would be allocated. Exposures to commercial settlement banks are concentrated, moving the management of credit risk outside the system (between CHAPS members and their bank clients). Membership in CHAPS is fair and open. Governance arrangements could be improved to reflect the fact that the operator of

\footnotetext{
${ }^{11}$ In March 2007, the Payments Council and Payments Administration replaced The Association for Payment Clearing Services (or APACS).
} 
CHAPS is also the operator of the Faster Payments Service, which is at a much earlier stage of development: CHAPSCo needs to demonstrate that it has the resources and capacity to satisfy the needs of both schemes. It also needs to show improvements to succession planning following the retirement of the Company Manager. CHAPS is competently overseen by the BoE, which has a well-defined oversight role based in statute, as well as an operational role as operator of the underlying RTGS infrastructure. However, the BoE does not undertake a direct and unified assessment of the RTGS infrastructure against these Core Principles.

105. Legal framework (CP I): CHAPS operates under a well-founded legal basis that is reinforced by its designation under the Financial Markets and Insolvency Regulations, which implements the EU Settlement Finality Directive in the United Kingdom. The legal basis for the BoE's oversight of CHAPS is established in statute under Part 5 of the Banking Act 2009, which also provides the BoE with statutory tools to assist its oversight function. All CHAPS members agree to the CHAPS Rules, which incorporate by reference other relevant documents. There is a clear contractual relationship between CHAPS members and the BoE as provider of the underlying RTGS infrastructure for CHAPS and intra-day credit within the system. There is a MOU between CHAPSCo and the BoE setting forth detailed service level expectations in key areas. While the MOU is not a binding legal contract, incentives are wellaligned between the BoE and CHAPSCo, and thus the potential for misunderstanding or an irresolvable dispute between the two parties, requiring resort to legal action, remains small. However, the BoE should undertake a legal review of the consequences of the nonbinding nature of the MOU, either internally via the BoE's legal department, or externally.

106. Understanding and Management of Risks (CP II-III): As a general matter, the CHAPS Rules enable the members to have a clear understanding of the risks they face through participation in the system. In normal and contingency operations, the points of irrevocability and finality are clearly defined. Members are aware of the controls in place to help them manage liquidity risk, such as throughput guidelines, offsetting algorithms for queued payments, and the Sterling Bank Liquidity Scheme, which can help with the recycling of trapped liquidity. Members are also aware of and regularly test the measures designed to help them manage operational risk, such as the ability to make payments via the Enquiry Link or authorized fax, or the RTGS Bypass mode which can be invoked if the BoE's primary and standby systems are unavailable to process settlement requests for an extended period of time. In normal operations, members do not face credit risk since payments are settled on a real-time gross basis. However, in Bypass mode, payments would settle on a multilateral net basis at the end of each settlement cycle, which could expose members to credit risk. To help members understand and manage the risks they face in Bypass mode, CHAPSCo should develop procedures to set forth how losses would be allocated in the extremely unlikely event that a participant in a net debit position were to default while in Bypass mode. 
107. Settlement (CP IV-VI): Settlement finality occurs in real time on a gross basis and in central bank money, upon the debiting and simultaneous crediting of the relevant members' settlement accounts at the BoE. In Bypass mode, settlement occurs on a multilateral net basis at the end of each settlement cycle. It is expected that two settlement cycles will be run in order to prevent the build-up of net debit positions (one in the middle of the afternoon, and one at the end of the day), but more frequent settlement cycles could be run if it were thought necessary. As previously discussed, CHAPSCo should develop processes and procedures to ensure that final settlement can take place in Bypass mode, if there were a default of a participant in a net debit position. While CHAPS settles in central bank money, a significant amount of large-value payment activity in the United Kingdom settles in commercial bank money on the books of the most active CHAPS members. This is a potential source of vulnerability since, if a major clearer were to become unavailable, this would likely impose significant liquidity pressures. The BoE is well aware of the risks associated with tiering, and has spent considerable effort in raising the awareness of such risks and encouraging banks with significant activity in the second tier to become direct members. Direct participation in CHAPS has recently increased with J.P. Morgan and Bank of America both becoming CHAPS members in the second half of 2010, but settlement remains highly concentrated.

108. Operational Reliability and Efficiency (CP VII-VIII): CHAPS offers a high degree of security and operational reliability. CHAPS members and suppliers must comply with the CHAPS Security Policy and Security Code of Conduct, and there is a comprehensive process for confirming members' compliance. As operation of the core operational infrastructure is outsourced to the BoE, the MOU between $\mathrm{CHAPS}$ and the BoE specifies important operational performance and reliability targets that the BoE has historically met. The BoE operates a hot back-up site, providing resilience to operational shocks. However, the two processing sites are only around 12 miles apart as the crow flies and therefore still exposed to the risk of a wide-area event. To buttress resilience further, CHAPSCo and the BoE are considering whether to subscribe to the SWIFT Market Infrastructure Resilience Service, which is a generic RTGS. This service would replace the Bypass mode in the event both of the BoE's operational sites were down. Contingency options are regularly tested, including with members. Discussions with members suggest that CHAPS provides an efficient solution for making large-value payments in a reliable and safe manner.

109. Access and Governance (CP IX-X): Membership in CHAPS is fair and open, with membership criteria publicly disclosed on the CHAPSCo website. Discussions with market participants suggest the main barrier to entry may be a lack of a business case. The CHAPSCo Board, which is comprised only of CHAPS and FPS members, has responsibility for managing the system and Board decisions are made on a consensus basis. Member engagement also takes place through the member-led committees. The governance structure and fees could be made more transparent, which could help a prospective member develop a complete business case. CHAPSCo is also the operator of FPS, and this raises challenges 
with respect to governance and management, particularly given that the CHAPS and FPS are at entirely different stages of development. Therefore, CHAPSCo needs to demonstrate that it has the resources and capacity to satisfy the needs of both schemes. The BoE has identified this as an issue, and the CHAPSCo governance structure is being revised.

110. Central Bank Responsibilities (A-D): The BoE has clearly defined objectives with regard to payment system oversight. Under Part 5 of the Banking Act 2009, interbank payment systems can be recognized by the Treasury and brought under the BoE's oversight regime. The recognized systems are: CHAPS; CLS; Bacs; FPS; and the inter-bank payment systems operated as part of CREST, LCH, and ICE. Operators of recognized payment systems must have regard for the principles set forth by the $\mathrm{BoE}$, and the $\mathrm{BoE}$ uses the 10 Core Principles plus four additional principles covering business risk, interdependencies, indirect participants, and outsourcing. The BoE follows a program of risk reviews for each of the recognized systems, the outcome of which is used to set the BoE's expectations for actions to be taken by the operator. In discharging its oversight obligations, the BoE cooperates effectively with domestic authorities, such as the FSA, and foreign authorities, such as other central banks. In addition to its oversight role, the BoE operates the RTGS infrastructure, which provides RTGS for CHAPS and CREST, as well as settlement for other payment schemes (FPS, Bacs, Cheque and Credit Clearing, LINK). The RTGS also facilitates intraday liquidity transfers, reserve account transfers, transfers in respect of the note circulation system, and transfers that can occur outside of CHAPS operating hours. The $\mathrm{BoE}$ assesses the RTGS infrastructure against the Core Principles in an indirect and fragmented manner through its oversight of recognized systems that rely on the RTGS for settlement. Given that not all RTGS activity relates to these overseen systems, and the importance of the RTGS to the U.K. financial system, the BoE should undertake a direct, unified assessment of the RTGS, systemically evaluating it against the Core Principles. This should include an assessment of the finality of RTGS movements made outside the context of systems designated under the Settlement Finality Regulations. 
Table 8. Recommended Action Plan to Improve Observance of the CPSIPS and Central Bank Responsibilities in Applying the CPs

\begin{tabular}{|l|l|}
\hline Reference Principle/Responsibility & \multicolumn{1}{|c|}{ Recommended Action } \\
\hline Core Principle III & $\begin{array}{l}\text { CHAPSCo should develop procedures to make clear where } \\
\text { losses would fall were a member in a net debit position to default } \\
\text { while in Bypass mode. At the time of assessment, CHAPSCo was } \\
\text { considering how to ensure that settlement can complete in the } \\
\text { event of a member default while in Bypass mode, making clear } \\
\text { where losses would fall. In the medium term, CHAPSCo and the } \\
\text { BoE are considering a back-up RTGS system that would replace } \\
\text { the Bypass mode in the event that both of the BoE's operational } \\
\text { sites are down. }\end{array}$ \\
\hline Core Principle X & $\begin{array}{l}\text { CHAPSCo should demonstrate that it can simultaneously manage } \\
\text { both the CHAPS and FPS schemes, which is complicated by the } \\
\text { fact they are at entirely different stages of development. } \\
\text { CHAPSCo should also demonstrate improvements to its } \\
\text { succession planning. It is expected that improvements to } \\
\text { governance are forthcoming following an external review of these } \\
\text { arrangements. The BoE has provided important input to this } \\
\text { governance review on matters such as Board composition, senior } \\
\text { manager appointments, and the operation of multiple schemes. A } \\
\text { report has been completed and planning for implementation is } \\
\text { underway. }\end{array}$ \\
\hline Central Bank Responsibility B & $\begin{array}{l}\text { The BoE should formally assess the RTGS infrastructure's } \\
\text { compliance with the Core Principles in a unified manner, given } \\
\text { that not all activity in the RTGS infrastructure relates to systems } \\
\text { that the BoE oversees, and given the importance of the RTGS } \\
\text { infrastructure to the U.K. financial system. }\end{array}$ \\
\hline & \\
\hline
\end{tabular}




\section{Table 9. Additional Recommendations to Go Beyond Observance of the CPSIPS and Central Bank Responsibilities in Applying the CPs}

\begin{tabular}{|l|l|}
\hline Reference Principle/Responsibility & \multicolumn{1}{|c|}{ Recommended Action } \\
\hline Core Principle I & $\begin{array}{l}\text { While the incentives between the BoE and CHAPSCo appear to } \\
\text { be well-aligned, the analysis undertaken by the BoE's oversight } \\
\text { area on the lack of a binding contract between the two parties } \\
\text { should be supplemented by a legal review of the consequences of } \\
\text { the nonbinding nature of the MOU, either internally via the BoE's } \\
\text { legal department, or externally. The BoE indicated that its legal } \\
\text { department is undertaking this supplementary legal review. }\end{array}$ \\
\hline Core Principle VI & $\begin{array}{l}\text { The BoE should continue its efforts to raise awareness of the } \\
\text { risks of tiering, and where practical, continue to encourage direct } \\
\text { participation in the system. The high concentration of payments in } \\
\text { two settlement banks should be monitored by banking } \\
\text { supervisors. Although these banks are very large and well- } \\
\text { supervised banks, it is important that the relevant banking } \\
\text { supervisors account for the systemically important payments and } \\
\text { concentrations of payments for these two banks. }\end{array}$ \\
\hline Core Principle VII & $\begin{array}{l}\text { CHAPSCo and the BoE are encouraged to proceed with the } \\
\text { objective of implementing an RTGS back-up solution to replace } \\
\text { the Bypass mode. This solution is still in the planning phase and } \\
\text { is subject to project approval. If approved, preliminary timelines } \\
\text { estimate a delivery date of 2013/2014. }\end{array}$ \\
\hline Core Principle IX & $\begin{array}{l}\text { CHAPSCo is encouraged to make the CHAPS Rules and fees } \\
\text { public. }\end{array}$ \\
\hline Core Principle X & $\begin{array}{l}\text { The CHAPS governance structure could be made more } \\
\text { transparent; for example, the governance arrangements could be } \\
\text { published on the CHAPS website accessible to the public. }\end{array}$ \\
\hline
\end{tabular}




\section{Authorities' Response}

111. The U.K. authorities welcome this assessment of the CHAPS payment system against the CPSS Core Principles for Systemically Important Payment Systems and of the BoE against the Central Bank Responsibilities in Applying the Core Principles.

112. The assessment identifies actions, which would improve observance and also makes additional recommendations. The U.K. authorities will consider and review the assessors' recommendations and additional actions. As noted in the assessment, work on many is already in train.

\section{The IMF recommends that the BoE should "formally assess the RTGS} infrastructure's compliance with the Core Principles in a unified manner, given that not all activity in the RTGS infrastructure relates to systems that the BoE oversees, and given the importance of the RTGS infrastructure to the U.K. financial system." As noted in the report, RTGS is not an interbank payment system but an accounting infrastructure that supports some payment systems. It would therefore not be appropriate to assess RTGS against the CPSS Core Principles as they apply to Payment Systems. The BoE will, however, this year conduct a unified assessment of RTGS based on its existing internal risk assessment, monitoring and management framework. That will be done at arm's length as well as by line management.

\section{CPSS/IOSCO RECOMMENDATIONS FOR SECURITIES SETTLEMENT SYSTEMS- CREST $^{12}$}

\section{A. Information and Methodology Used for Assessment}

114. This assessment was undertaken in the context of an IMF FSAP exercise for the United Kingdom in January 2011 which included, inter alia, the Recommendations for Securities Settlement Systems (RSSS). ${ }^{13}$ This assessment covers the CREST securities settlement system (CREST) operated by Euroclear U.K. \& Ireland Limited (EUI), which is the Central Securities Depository (CSD) of the U.K., Ireland, Jersey, Guernsey and the Isle of Man. EUI is a wholly owned subsidiary of the Euroclear SA/NV Group based in Belgium. Euroclear SA/NV provides and supports the technical CREST services for EUI, but EUI is the U.K. regulated body and the Board of Directors of EUI is responsible for providing the CREST service to the United Kingdom and Irish markets.

\footnotetext{
12 The assessor was Christine Sampic, IMF Senior Financial Sector Expert, in collaboration with Nikil Chande, Principal Researcher in the Department of Financial Stability at Bank of Canada.

${ }^{13}$ Issued in November 2001 by the Committee on Payment and Settlement Systems (CPSS) and the Technical Committee of IOSCO.
} 
115. The assessors reviewed several previous assessments and held discussions with relevant parties. During the 2002 FSAP, a detailed assessment was made of CREST against the RSSS. A follow-up of this assessment was undertaken as a selected issue in the context of the 2005 Article IV consultation. The FSA and BoE conducted a formal assessment of CREST's observance of the RSSS in 2005 and published it in June 2006. In addition, a new assessment was prepared by the FSA with the BoE's input on CREST payment arrangements for Recommendations 7, 8, and 10 in December 2010 for the FSAP mission. The FSA also provided a number of documents relevant for the assessment. Extensive meetings were held with officials from the FSA and the BoE, supplemented by discussions with officials from EUI as well as with representatives of four CREST participants and two stock-exchanges. No obstacles were faced in the work. The authorities and others were fully cooperative.

\section{The assessment methodology for "Recommendations for Securities Settlement Systems" issued by the CPSS/IOSCO in November 2002 was used when assessing CREST.}

\section{B. Institutional and Market Structure-Overview}

117. U.K. equities are traded across a number of trading platforms, including exchanges and Multilateral Trading Facilities (MTFs), and in the OTC market and cleared via four central counterparties (CCPs). Currently, there are two U.K.-based CCPs that clear securities: (i) LCH. Clearnet Limited, a wholly owned subsidiary of the U.K./France based LCH. Clearnet group; and (ii) EuroCCP, a wholly owned subsidiary of the US based DTCC. ${ }^{14}$ In addition, two CCPs that hold a Recognized Overseas Clearing House license clear U.K. securities: EMCF based in the Netherlands and SIX X-clear AG based in Switzerland.

118. In 2010, in terms of value, around 60 percent of equities were traded on the London Stock Exchange (LSE) and cleared via LCH. Clearnet Limited and SIX x-clear. The remainder of equity trading was undertaken over-the-counter, and through the MTFs, mostly Chi-X, BATS and Turquoise, with Chi-X and BATS cleared by EMCF, and Turquoise cleared by Euro CCP (Figure 1). The PLUS Markets exchange offers trading in the alternative, junior equities market (AIM) and is cleared by LCH. Clearnet Limited. Transactions are settled in CREST; Euroclear Bank SA/NV (Euroclear), the Brussels based International Central Securities Depository (ICSD); and SegaInterSettle (SIS), the Zurich based ICSD.

\footnotetext{
${ }^{14}$ Depository Trust \& Clearing Corporation.
} 
Figure 1. Exchanges, MTFs, and CCPs settling in CREST

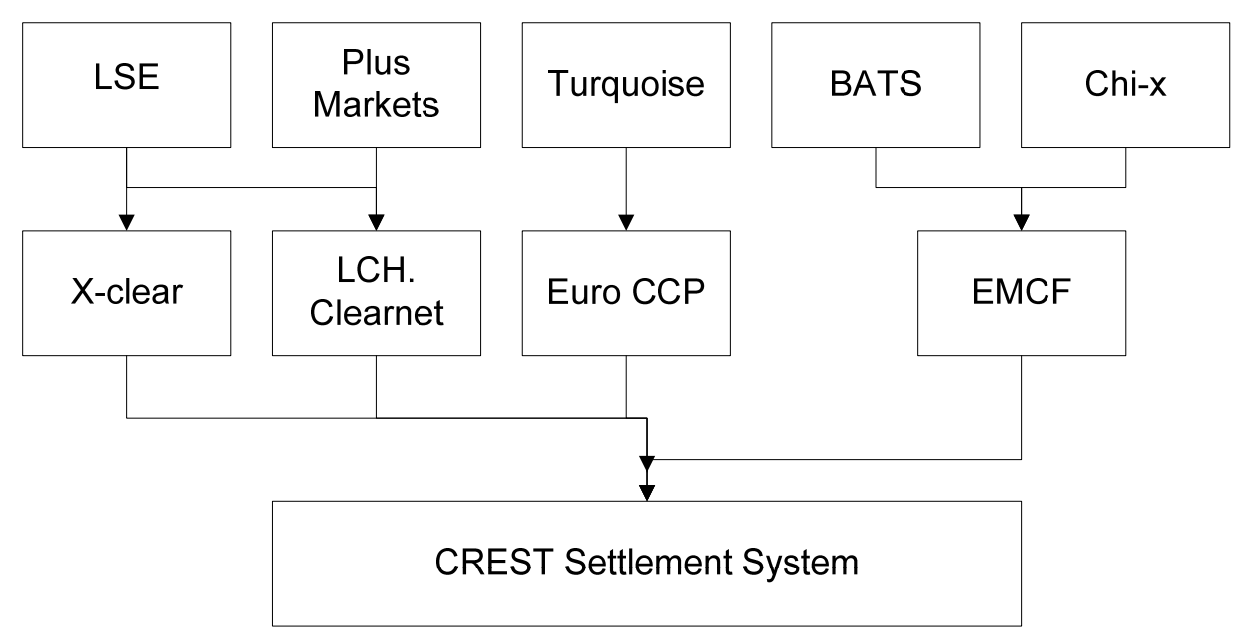

119. Bond trading is undertaken via MTFs, bilateral trading systems, and voice brokers. Part of it is centrally cleared by LCH.Clearnet Limited. Gilts and U.K. registered corporate debt instruments are settled in CREST.

120. CREST settles and holds a wide range of securities. This includes U.K. and Irish equities, gilts, corporate debt, money market instruments, warrants, and English Law depository receipts that represent international securities (equities, Eurobonds, and international warrants). CREST provides a delivery versus payment (DvP) settlement service in three currencies: sterling, euro and US dollars. In sterling and euro, interbank cash settlement is on a RTGS basis in central bank money. The US dollar payment arrangements involve bilateral net interbank cash settlement after the end of the CREST settlement day, at a time and in a manner bilaterally agreed between each settlement bank. CREST also provides other services including collateral facilities, securities borrowing and lending functions, tax assistance and stamp duty, corporate actions facilities, and transaction reporting to the U.K. and Irish regulators.

121. In 2010, on average the CREST system settled around 240,000 transactions on a daily basis with a value of around $£ 0.6$ trillion ( $£ 1.6$ trillion including the selfcollateralized repos), of which 99.5 percent were settled in sterling, 0.2 percent in U.S. dollar, and 0.1 percent in euro. The U.K. Government bonds (gilts) and money market instruments account for approximately 88 percent of the value of settlement. The value of securities held in CREST amounted to more than $£ 3.3$ trillion, of which 60 percent were equities.

\section{Regulatory Structure-Overview}

122. EUI is authorized as an operator of a relevant system under the Uncertificated Securities Regulations 2001 and is regulated in the United Kingdom by the FSA as a Recognized Clearing House under the Financial Services and Markets Act 2000. EUI is 
also authorized as an operator of systems in Ireland, Jersey, and the Isle of Man. CREST is a designated system in the United Kingdom and Ireland under the Settlement Finality Directive.

123. The BoE oversees EUI as an operator of an inter-bank payment system under Part 5 of the Banking Act 2009, which establishes a statutory regulatory regime for interbank payment systems. The Treasury recognized the embedded payment arrangements within CREST as an inter-bank payment system in January 2010. CREST is one of the largest embedded payment systems in the United Kingdom with daily cash movements of $£ 1.6$ trillion (including self-collateralized repos). The BoE and the FSA signed a MOU regarding the oversight of payments systems, which covers FSA regulated entities such as EUI that have embedded payment systems.

124. A joint College of Regulators, with representatives of each member country of the Euroclear Group (United Kingdom/Ireland, France, Belgium, Netherlands, Sweden and Finland), meets quarterly and seeks to ensure a coordinated regulatory approach. A MOU agrees the extent and methodology of cooperation between the participants.

\section{Main Findings}

125. The overall assessment is that the CREST system itself is reliable and effective in providing delivery versus payment settlement on a real time gross basis. There is however a residual interbank credit risk stemming from the USD settlement mechanism. EUI's supervision and oversight are risk-based and thus are implemented on a prioritization basis. They have been strengthened since the crisis, both at the BoE and the FSA. Still, at least 15 percent of equities by value and around 1 percent of gilts by value are not dematerialized, which involves operational costs for market participants. Exposures to commercial settlement banks are highly concentrated and growing, increasing credit risk outside the system.

\section{Legal framework (Rec. 1)}

126. The settlement activities in the United Kingdom are governed by a consistent set of laws, regulations, and contractual arrangements that form a sound legal foundation for settlement and custody activities. The legal regulatory framework is clear and transparent. The United Kingdom's implementation of European directives provides a firm statutory foundation for netting, set-off and securities lending, consistently with the other member states. Both securities and payment transfers, when finalized, and default arrangements are protected from the ordinary operation of U.K. and Ireland insolvency laws.

Pre-settlement risk (Rec. 2-5)

127. Most trades between direct market participants are due to be confirmed the same day and settled on a continuous basis, using a rolling settlement cycle, three days after trade execution for equities, and between zero and three days for debt instruments 
(depending on the type of instrument and its maturity). The assessors did not obtain the data to assess the performance of the securities trade confirmation process between direct market participants, and were not able to assess the performance of trade confirmation at the indirect participant level either.

128. The United Kingdom has well-developed securities lending and repo markets that contribute to the settlement process. They are clearly acknowledged in, and supported by, law, regulation, tax, and accounting systems. There is no specific regulatory regime for securities lending and repo markets, which are governed by contractual arrangements and codes of practice.

\section{Settlement risk (Rec. 6-10)}

129. Since the 2002 FSAP, money market instruments have been fully dematerialized, which is a significant achievement. However, in 2010, at least 15 percent of equities by value and around 1 percent of gilts by value were still not dematerialized, which involves operational costs for market participants. Following the 2009 General Election, the U.K. Government considered dematerialization carefully, and concluded that it was not a priority, particularly given that there was not an overall consensus amongst interested stakeholders.

130. DvP is achieved through the simultaneous transfer of funds and securities when settlement is executed in CREST accounts. CREST offers 'model 1' DvP for sterling and euro transactions. For US dollar transactions, CREST offers 'model 2' DvP. For US dollar settlement, although cash and securities move in CREST on a transaction by transaction basis throughout the settlement day, the settlement banks bilaterally discharge their net payment obligations with each other arising from CREST settlement after the end of the CREST settlement day. They settle these payment obligations at a time and in a manner bilaterally agreed between themselves. There is an interbank credit risk stemming from this mechanism, which means that principal risk is not fully eliminated: if the paying CREST USD settlement bank fails, CREST members are exposed to the risk that having delivered a security, they fail to receive payment for it. However, USD transactions are presently small.

131. There is a potential risk of revocability of the Irish, Jersey, Guernsey, and Isle of Man securities in the two hours following settlement due to the time needed to register them in local registrars. But the grounds upon which a registrar may refuse to register a transfer is very limited and clearly defined in the relevant regulations. In addition, related activity is very small and the risk has never materialized yet.

\section{Where CREST Members share the same CREST Settlement Bank, the} transactions among them are called 'on-us transactions.' The proportion of sterling transactions that are 'on-us' has steadily increased from around 15 percent at the start of 2008 to 40 percent in December 2010, illustrating the concentration of the custodian business (although a significant part of the increase is from transactions between CREST Settlement Banks' own entities). In addition, exposures to commercial settlement banks are highly 
concentrated, since two of them account for around 50 percent of the settlement value in sterling, thus transferring credit risk outside the system. This is a potential source of vulnerability, since the unexpected unavailability of a major clearer would likely raise substantial liquidity pressures. Although these banks, which are very large, are wellsupervised banks, it is essential that this particular dimension is carefully reflected in the supervisory process.

Operational risk (Rec. 11)

133. The system is reliable and secure, and has adequate, scalable capacity. Contingency plans and back-up facilities are in place to allow for timely recovery of operations and completion of the settlement process. However, EUI does not organize compulsory contingency testing for its largest participants. CREST does not have a second IT back-up site (three IT sites architecture), which would be welcome for such a core infrastructure. A business case for a third IT site is underway with the aim of implementing it in 2012.

Custody risk (Rec. 12)

134. The CSD operates a "direct holding" system, where securities are registered in the name of the legal owner. It offers the possibility to open individual accounts.

135. The failure of Lehman Brothers International highlighted a number of areas where the protection of customers' securities against the claims of a custodian's creditors needed to be strengthened. However, it should be noted that no difficulties stemmed from assets registered in EUI.

Other issues (Rec. 13-19).

136. The CSD is owned by users and its Board of directors reflects the interest of shareholders, users, and the public interest. Rules, procedures, fees and major decisions are all published on its external website.

137. The CSD access criteria and the procedures for the exit of participants, whether initiated by the participant or by the CSD, are clearly stated in the participant rules and are disclosed on the CSD website. However, according to the CREST Rules, existing Settlement Banks could potentially veto an applicant Settlement Bank.

138. The CSD routinely reviews its pricing levels against its costs of operation. It also carries out user surveys and benchmarks its costs and charges against other systems. Ad-hoc surveys are also used to assess user satisfaction with the system and the service it provides.

139. The CSD rules and other contractual arrangements defining the rights and obligations of the participants are publicly available. The CSD has published its selfassessment against the $\mathrm{ESCB} / \mathrm{CESR}$ recommendations on its website. 


\section{The role and responsibilities of relevant public authorities with respect to} securities settlement activities are clearly defined and transparent. The CSD's supervision and oversight are risk-based and thus are implemented on a prioritization basis. They have been strengthened since the crisis, both at the BoE and the FSA. Hiring and keeping the right expertise is challenging for them.

\section{The CSD has established three links with foreign securities settlement systems.} Only one of them settles DvP, while the two others are free-of-payment. Under the current conditions, the links do not seem to expose the CSD to potential credit risk and financial losses.

\section{Table 10. Recommended Action Plan to Improve Observance}

\begin{tabular}{|l|l|}
\hline \multicolumn{1}{|c|}{$\begin{array}{c}\text { Reference } \\
\text { Recommendation }\end{array}$} & \multicolumn{1}{c|}{ Recommended Action } \\
\hline RSSS2 & $\begin{array}{l}\text { The regulatory authorities should monitor the performance of the trade } \\
\text { confirmation process between direct market participants. In addition, the } \\
\text { assessors encourage the U.K. authorities to work with market } \\
\text { participants to ensure a good confirmation performance at the indirect } \\
\text { participant level. }\end{array}$ \\
\hline RSSS10 & $\begin{array}{l}\text { Risk mitigation arrangements, such as exposure limits and a guarantee } \\
\text { fund, should be put in place to reduce the credit risk associated with the } \\
\text { USD settlement in commercial bank money. }\end{array}$ \\
\hline RSSS14 & $\begin{array}{l}\text { All the requirements to be a euro or sterling Settlement Bank should be } \\
\text { clearly defined in the CREST Rules. Existing Settlement Banks should } \\
\text { not be in a position to veto an applicant euro or sterling Settlement } \\
\text { Bank. }\end{array}$ \\
\hline
\end{tabular}

Table 11. Additional Action Plan

\begin{tabular}{|l|l|}
\hline \multicolumn{1}{|c|}{$\begin{array}{c}\text { Reference } \\
\text { Recommendation }\end{array}$} & \multicolumn{1}{c|}{ Recommended Action } \\
\hline RSSS6 & $\begin{array}{l}\text { For the sake of efficiency and European harmonization, the U.K. } \\
\text { authorities could consider a mandatory dematerialization, as in was the } \\
\text { case in many countries (e.g. France and Sweden). } \\
\text { Changes in the relevant legislation should eliminate the potential risk of } \\
\text { revocability of the Irish, Jersey, Guernsey, and Isle of Man securities in } \\
\text { the two hours following settlement. Meanwhile, it is important that this } \\
\text { risk is not forgotten in the supervisory process. }\end{array}$ \\
\hline RSSS7 & $\begin{array}{l}\text { EU should implement alternative payment arrangements that can } \\
\text { reduce the credit risk associated with the USD settlement (such as } \\
\text { exposure limits and guarantee fund), in order to be prepared in case of } \\
\text { an increase in USD settlement activity. In addition, it is important that } \\
\text { supervisors are aware of this risk exposure and can discuss it with } \\
\text { banks in their risk assessments. }\end{array}$ \\
\hline
\end{tabular}




\begin{tabular}{|l|l|}
\hline \multicolumn{1}{|c|}{$\begin{array}{c}\text { Reference } \\
\text { Recommendation }\end{array}$} & \multicolumn{1}{c|}{ Recommended Action } \\
\hline RSSS10 & $\begin{array}{l}\text { The high concentration of activities in two settlement banks should be } \\
\text { monitored by banking supervisors. Although these banks are very large } \\
\text { and well-supervised, it is important that this particular dimension is } \\
\text { carefully reflected in the supervisory process. }\end{array}$ \\
\hline RSSS11 & $\begin{array}{l}\text { EUl should involve its largest participants in contingency testing on a } \\
\text { compulsory basis. }\end{array}$ \\
A third IT site would be welcome for such a core market infrastructure. \\
\hline
\end{tabular}

\section{E. Authorities' Response}

142. The U.K. authorities welcome this assessment of the CREST settlement system against the CPSS/IOSCO RSSS.

\section{The United Kingdom's supervision and oversight of EUI, the operator of the} CREST system has changed since the financial crisis. It is therefore reassuring that the IMF notes the strengthened supervision and oversight of EUI.

144. The assessment identifies recommended actions which would improve observance with the RSSS. The U.K. authorities will consider and review all of the assessors' recommendations and additional actions, and look to use ongoing supervision and oversight to ensure U.K. settlement arrangements remain robust and resilient.

145. Finally, the authorities wish to express their strong support of the FSAP initiative and look forward to a continuing dialogue with the IMF and other global counterparts to seek to improve the stability and effective supervision of the global financial system.

\section{CPSS/IOSCO RECOMMENDATIONS FOR CENTRAL COUNTERPARTIES- LCH.CLEARNET LIMITED ${ }^{15}$}

\section{A. Information and Methodology Used for Assessment}

146. This assessment was undertaken in the context of an IMF FSAP exercise for the United Kingdom in January 2011 which included, inter alia, the Recommendations for Central Counterparties (RCCP). This assessment covers LCH.Clearnet Limited (LCH), the main CCP active in the U.K.'s financial markets. LCH is a wholly owned subsidiary of

\footnotetext{
15 The assessment was conducted by Christine Sampic, IMF Senior Financial Sector Expert, and Nikil Chande, Principal Researcher in the Department of Financial Stability at Bank of Canada.
} 
LCH.Clearnet Group Limited, which is a private company, limited by shares and registered in the United Kingdom.

147. The assessors reviewed relevant documentation provided by the FSA and held discussions with relevant parties. In June 2006, LCH was assessed by the FSA and the BoE against the RCCPs for the first time. In 2009, LCH conducted a self-assessment against the RCCPs. The FSA reviewed it, together with additional material requested in support of it, and validated it at end-2009, with the BoE's input on recommendations relating to LCH's payment arrangements. For the FSAP mission, the FSA provided the 2009 assessment, which is published on LCH Clearnet's website, and a summary of the main changes having affected the system since then. It also provided a number of documents relevant for the assessment. Extensive meetings were held with officials from the FSA and the BoE, supplemented by discussions with officials from $\mathrm{LCH}$ as well as with three LCH members and settlement banks, and two exchanges. No obstacles were faced in the work. The authorities and others were fully cooperative.

148. The assessment methodology used was the one developed together with the CCP recommendations by the CPSS/IOSCO in 2004.

\section{B. Institutional and Market Structure-Overview}

149. LCH is one of the main CCPs in Europe, serving major international exchanges and platforms, as well as a range of OTC markets. It clears a broad range of asset classes including: securities, exchange traded derivatives, energy, freight, interbank interest rate swaps, and euro and sterling denominated bonds and repos. LCH operates in a number of currencies, ${ }^{16}$ among which the main ones are sterling, euro and U.S. dollar. LCH provides CCP services for:

- $\quad$ London Stock Exchange (LSE);

- $\quad$ NYSE Euronext.LIFFE (LIFFE);

- $\quad$ London Metal Exchange (LME);

- $\quad$ EDX London;

- $\quad$ SIX Swiss Exchange;

- $\quad$ Nodal Exchange; and

- $\quad$ Several European Multilateral Trading Facilities (MTFs).

150. In addition, it offers a number of OTC derivatives services, most notably SwapClear for interest rate swap and RepoClear for cash bond and repo trades in the following markets: Austrian, Belgian, Dutch, German, Irish, Finnish, Portuguese,

\footnotetext{
${ }^{16}$ Australian dollar, Canadian dollar, Swiss franc, Czech koruna, Danish kroner, euro, sterling, Hong Kong dollar, Hungarian forint, Islandic krona, Japanese yen, Norwegian krone, New Zealand dollar, Polish zloty, Swedish krona, South African rand, and the US dollar.
} 
Slovakian, Slovenian, Spanish and U.K. government bonds. LCH is the largest global clearing facility for interest rate swaps, and the second largest for fixed income trading and repo contracts.

\section{Regulatory Structure-Overview}

151. Regulation and oversight of $\mathrm{LCH}$ is carried out by the FSA and the BoE. The FSA is the main regulator of $\mathrm{LCH}$ as a Recognized Clearing House, while the BoE's oversight remit focuses on LCH's inter-bank payment system.

152. February 2011 Treasury's consultation indicates that the Government intends to transfer regulation and supervision of CCPs to the BoE by end-2012. Under the proposed framework, the BoE will be directly responsible for supervising the providers of systemically important infrastructure. It will, therefore, remain the regulator of payment systems under Part 5 of the Banking Act 2009, and it will take over the FSA's responsibility for regulating settlement systems under the Uncertificated Securities Regulations 2001. The BoE will also be the regulator of central counterparties under the FSMA. This will bring the regulation of all three types of body together for the first time.

\section{Main Findings}

153. The CCP is a user-owned, constrained-for-profit organization (i.e., beyond a certain threshold, profit goes back to users). Its risk management framework is robust. In particular, it regularly measures and manages its exposures to members, and this is done using intraday positions in all markets calculated hourly, except the LIFFE market, which is a routine capacity that should be developed. LCH's liquidity management is conservative, but it should put in place other safe and reliable funding options, including committed credit lines, to help it face extreme but plausible circumstances, such as disruptions to its tri-party repo arrangements or dislocations in the repo market. LCH secures its collateral pursuant to a conservative custody and investment policy, but it needs to confirm that its custodians' accounting practices and safekeeping procedures fully protect customers' securities. LCH mainly uses a private settlement bank model, which exposes the CCP to intraday credit risk. LCH should find a way to reduce its settlement exposures, with settlement in central bank money when possible and practical. The CCP's supervision and oversight are risk-based and thus are implemented on a prioritization basis. They have been strengthened since the crisis, both at the BoE and the FSA. 
Table 12. United Kingdom: Summary Observance

\begin{tabular}{|c|c|}
\hline Responsibility & Comments \\
\hline \multicolumn{2}{|l|}{ Legal risk } \\
\hline $\begin{array}{l}\text { 1. Central counterparties should } \\
\text { have a well-founded, clear and } \\
\text { transparent legal basis in the } \\
\text { relevant jurisdiction. }\end{array}$ & $\begin{array}{l}\text { A clear legal basis exists for } \mathrm{LCH} \text { to act as a CCP, and for its } \\
\text { netting arrangements, rights in collateral, and its procedures } \\
\text { upon default. Where necessary, } \mathrm{LCH} \text { protects itself further by } \\
\text { obtaining or requiring legal opinions. }\end{array}$ \\
\hline \multicolumn{2}{|l|}{ Participation requirement } \\
\hline $\begin{array}{l}\text { 2. A CCP should require } \\
\text { participants to have sufficient } \\
\text { financial resources and robust } \\
\text { operational capacity to meet } \\
\text { obligations arising from } \\
\text { participation in the CCP. A CCP } \\
\text { should have procedures in place } \\
\text { to monitor that participation } \\
\text { requirements are met on an on- } \\
\text { going basis. A CCP's } \\
\text { participation requirements } \\
\text { should be objectives, publicly } \\
\text { disclosed, and permit fair and } \\
\text { open access. }\end{array}$ & $\begin{array}{l}\text { LCH sets and monitors requirements for its members. These } \\
\text { depend on and are commensurate with the type of } \\
\text { membership and the markets to be cleared. They include } \\
\text { minimum levels of financial resources and credit worthiness, } \\
\text { and an appropriate level of operational capacity. }\end{array}$ \\
\hline \multicolumn{2}{|l|}{$\begin{array}{l}\text { Measurement and } \\
\text { management of credit } \\
\text { exposures }\end{array}$} \\
\hline $\begin{array}{l}\text { 3. A CCP should measure its } \\
\text { credit exposure to its participants } \\
\text { at least once a day. Through } \\
\text { margin requirements, other risk } \\
\text { control mechanisms or a } \\
\text { combination of both, a CCP } \\
\text { should limit its exposure to } \\
\text { potential losses from defaults of } \\
\text { its participants in normal market } \\
\text { conditions so that the operation } \\
\text { of the CCP would not be } \\
\text { disrupted and nondefaulting } \\
\text { participants would not be } \\
\text { exposed to losses that they } \\
\text { cannot anticipate or control. }\end{array}$ & $\begin{array}{l}\text { LCH regularly measures its exposures to members, and this is } \\
\text { done using intraday positions in all markets except the LIFFE } \\
\text { one. LCH should develop a routine capacity for doing so in the } \\
\text { LIFFE market. LCH limits its exposures to potential losses } \\
\text { from default through a variety of measures, including } \\
\text { membership requirements, collection of initial margin including } \\
\text { additional margin where necessary, contributions to a default } \\
\text { fund, and the monitoring of position limits. Even though there } \\
\text { is risk of mutualization through a single default fund, the main } \\
\text { focus is on initial margins, mostly following a defaulter-pay } \\
\text { model. }\end{array}$ \\
\hline
\end{tabular}




\begin{tabular}{|c|c|}
\hline Margin requirements & \\
\hline $\begin{array}{l}\text { 4. If a CCP relies on margin } \\
\text { requirements to limit its credit } \\
\text { exposures to participants, these } \\
\text { requirements should be } \\
\text { sufficient to cover potential } \\
\text { exposures in normal market } \\
\text { conditions. The models and } \\
\text { parameters used in setting } \\
\text { margin requirements should be } \\
\text { risk-based and reviewed } \\
\text { regularly. }\end{array}$ & $\begin{array}{l}\text { LCH uses various initial margin models for the different } \\
\text { markets it clears, such as SPAN, PAIRS, and ERA. Its } \\
\text { margining assumptions are generally conservative, and it } \\
\text { regularly backtests the intended coverage. LCH can and does } \\
\text { make both routine and ad hoc intraday margin calls, subject to } \\
\text { a minimum transfer threshold. For the LIFFE market, if prices } \\
\text { are particularly volatile, then LCH will make an intraday call } \\
\text { based on the previous day's positions. LCH should develop a } \\
\text { routine capacity to do so using current positions. LCH takes a } \\
\text { conservative approach with regard to its collateral eligibility for } \\
\text { initial margin. }\end{array}$ \\
\hline \multicolumn{2}{|l|}{ Financial resources } \\
\hline $\begin{array}{l}\text { 5. A CCP should maintain } \\
\text { sufficient financial resources to } \\
\text { withstand, at a minimum, the } \\
\text { default of a participant to which it } \\
\text { has the largest exposure in } \\
\text { extreme but plausible market } \\
\text { conditions. }\end{array}$ & $\begin{array}{l}\text { LCH has designed its default fund, which is comprised only of } \\
\text { cash, in order that it will have sufficient resources to cover } \\
\text { more than the single largest default. This is tested daily using } \\
\text { historical and theoretical scenarios, with end-day positions. In } \\
\text { the event of a default, LCH needs access to sufficient liquidity } \\
\text { to fulfill its obligations in a timely manner. LCH's liquidity } \\
\text { management is comprehensive and conservative, but it } \\
\text { should put in place other safe and reliable funding options, } \\
\text { which should include committed credit lines subject only to } \\
\text { presentment, and could also include other options like } \\
\text { mutualization of liquidity risk among the CCP's membership. } \\
\text { This would help it face extreme but plausible circumstances, } \\
\text { such as disruptions to its tri-party repo arrangements or } \\
\text { dislocations in the repo market. }\end{array}$ \\
\hline \multicolumn{2}{|l|}{ Default procedures } \\
\hline $\begin{array}{l}\text { 6. A CCP default procedures } \\
\text { should be clearly stated, and } \\
\text { should ensure that the CCP can } \\
\text { take timely action to contain } \\
\text { losses and liquidity pressure and } \\
\text { to continue meeting its } \\
\text { obligations. Key aspects of the } \\
\text { default procedures should be } \\
\text { publicly available. }\end{array}$ & $\begin{array}{l}\text { In the event of a default, LCH has broad authority to close out } \\
\text { the defaulter's contracts, transfer its open contracts, and sell } \\
\text { its securities. LCH has an internal Default Management } \\
\text { Framework that provides a reference guide and high-level and } \\
\text { detailed operational procedures manual to assist in the } \\
\text { process of managing issues that will arise as a consequence } \\
\text { of a default. In the event of a default, it would be in close } \\
\text { contact with its regulators. LCH has successfully managed } \\
\text { five defaults, and discussions with regulators and market } \\
\text { participants suggest that the Lehman default was managed } \\
\text { effectively. }\end{array}$ \\
\hline \multicolumn{2}{|l|}{ Custody and investment risk } \\
\hline $\begin{array}{l}\text { 7. A CCP should hold assets in a } \\
\text { manner whereby risk of loss or of } \\
\text { delay in its access to them is } \\
\text { minimized. Assets invested by a } \\
\text { CCP should be held in } \\
\text { instruments with minimal credit, } \\
\text { market and liquidity risks. }\end{array}$ & $\begin{array}{l}\text { LCH's Treasury Investment Policy is comprehensive and } \\
\text { conservative, with safety taking priority over revenue } \\
\text { maximization. The vast majority of cash is secured, and the } \\
\text { policy outlines minimum credit rating criteria for its } \\
\text { counterparties, concentration limits at the counterparty group } \\
\text { level, diversification of assets, and criteria to mitigate interest } \\
\text { rate risk. Noncash collateral is mainly held at two European }\end{array}$ \\
\hline
\end{tabular}




\begin{tabular}{|c|c|}
\hline & $\begin{array}{l}\text { CSDs, and one custodian bank in the United States. LCH } \\
\text { needs to confirm that the US custodian it employs, and any } \\
\text { new custodians it uses, conform to the Recommendation } 12 \text { of } \\
\text { the RSSS (i.e., that they employ accounting practices and } \\
\text { safekeeping procedures that fully protect customers' } \\
\text { securities). }\end{array}$ \\
\hline \multicolumn{2}{|l|}{ Operational risk } \\
\hline $\begin{array}{l}\text { 8. A CCP should identify sources } \\
\text { of operational risk and minimize } \\
\text { them through the development of } \\
\text { appropriate systems, controls } \\
\text { and procedures. Systems should } \\
\text { be reliable and secure, and have } \\
\text { adequate, scalable capacity. } \\
\text { Business continuity plans should } \\
\text { allow for timely recovery of } \\
\text { operations and fulfillment of a } \\
\text { CCP's obligations. }\end{array}$ & $\begin{array}{l}\text { The system is reliable and secure, and has adequate, } \\
\text { scalable capacity. Contingency plans and back-up facilities } \\
\text { are in place to allow for timely recovery of operations and } \\
\text { completion of the settlement process. However, there is no } \\
\text { compulsory contingency testing for the largest participants, } \\
\text { and no second IT back-up site (three sites architecture). }\end{array}$ \\
\hline \multicolumn{2}{|l|}{ Money settlements } \\
\hline $\begin{array}{l}\text { 9. A CCP should employ money } \\
\text { settlement arrangements that } \\
\text { should eliminate or strictly limit } \\
\text { its settlement bank risks, that is, } \\
\text { its credit and liquidity risk from } \\
\text { the use of banks to effect money } \\
\text { settlements with its participants. } \\
\text { Funds transfers to a CCP should } \\
\text { be final when effected. }\end{array}$ & $\begin{array}{l}\text { LCH mainly uses a private settlement bank model, which } \\
\text { exposes the CCP to intraday credit risk. LCH should find a } \\
\text { way to reduce its settlement exposures, with settlement in } \\
\text { central bank money when possible and practicable. }\end{array}$ \\
\hline \multicolumn{2}{|l|}{ Physical deliveries } \\
\hline $\begin{array}{l}\text { 10. A CCP should clearly state } \\
\text { its obligations with respect to } \\
\text { physical deliveries. The risks } \\
\text { from these obligations should be } \\
\text { identified and managed. }\end{array}$ & $\begin{array}{l}\text { The CCP clearly states its obligations with respect to physical } \\
\text { deliveries. The risks from these obligations are identified and } \\
\text { managed. }\end{array}$ \\
\hline \multicolumn{2}{|l|}{ Risks in links between CCPs } \\
\hline $\begin{array}{l}\text { 11. CCPs that establish links } \\
\text { either cross-border or } \\
\text { domestically to clear trades } \\
\text { should evaluate the potential } \\
\text { sources of risks that can arise, } \\
\text { and ensure that the risks are } \\
\text { managed prudently on an } \\
\text { ongoing basis. There should be } \\
\text { a framework for cooperation and } \\
\text { coordination among the relevant } \\
\text { regulators and overseers. }\end{array}$ & $\begin{array}{l}\text { LCH currently interoperates with the Swiss CCP SIX x-clear in } \\
\text { the clearing of trades executed on the London Stock } \\
\text { Exchange and on the SIX Swiss Exchange; and with Oslo } \\
\text { Clearing for the EDX market. Each link is a peer-to-peer } \\
\text { model, in which both CCPs lodge initial margin with the other } \\
\text { CCP, and either CCP can be placed in default should it fail to } \\
\text { meet its contractual arrangement to the other CCP. Each CCP } \\
\text { calculates the margin it requires from the other using the } \\
\text { standard margin methodology it applies to its members. } \\
\text { However, neither CCP contributes resources to the other's } \\
\text { default fund, to minimize contagion risk from defaulting }\end{array}$ \\
\hline
\end{tabular}




\begin{tabular}{|c|c|}
\hline & $\begin{array}{l}\text { members between the CCPs. Inter CCP exposures are } \\
\text { collateralized. LCH has also applied to interoperate with } \\
\text { EuroCCP and EMCF. This is under review by the competent } \\
\text { authorities. }\end{array}$ \\
\hline \multicolumn{2}{|l|}{ Efficiency } \\
\hline $\begin{array}{l}\text { 12. While maintaining safe and } \\
\text { secure operations, CCPs should } \\
\text { be cost-effective in meeting the } \\
\text { requirements of participants. }\end{array}$ & $\begin{array}{l}\text { LCH has in place procedures to control its costs of operation } \\
\text { and undertakes regular analysis and benchmarking on } \\
\text { charges. Over the past three years, competition has led to } \\
\text { significant fee reductions. }\end{array}$ \\
\hline \multicolumn{2}{|l|}{ Governance } \\
\hline $\begin{array}{l}\text { 13. Governance arrangements } \\
\text { for a CCP should be clear and } \\
\text { transparent to fulfill public } \\
\text { interest requirements and to } \\
\text { support the objectives of owners } \\
\text { and participants. In particular, } \\
\text { they should promote the } \\
\text { effectiveness of a CCP's risk } \\
\text { management procedures. }\end{array}$ & $\begin{array}{l}\text { A three-year program, to align the ownership of the Group } \\
\text { more closely to its users through a significant share buyback, } \\
\text { came to an end in } 2009 \text {. LCH.Clearnet Group Limited is now } \\
\text { owned } 83 \text { percent by its users and } 17 \text { percent by exchanges } \\
\text { that clear through it. As a U.K. incorporated company, LCH's } \\
\text { Board and management are accountable to the shareholders. } \\
\text { The Board includes four independent board members } \\
\text { (including the Chairman). }\end{array}$ \\
\hline \multicolumn{2}{|l|}{ Transparency } \\
\hline $\begin{array}{l}\text { 14. A CCP should provide } \\
\text { market participants with sufficient } \\
\text { information for them to identify } \\
\text { and evaluate accurately the } \\
\text { costs and risks associated with } \\
\text { using its services. }\end{array}$ & $\begin{array}{l}\text { LCH publishes its rules and procedures for the various } \\
\text { markets cleared, together with information on risk } \\
\text { management, application costs and procedures, minimum } \\
\text { contributions towards (and interest rates on) the default fund, } \\
\text { and the transaction tariffs. Margin calculation models are } \\
\text { provided to the participants; but not the CCP's activity } \\
\text { statistics, nor its detailed objectives and the extent to which } \\
\text { they are met. }\end{array}$ \\
\hline \multicolumn{2}{|l|}{ Regulation and oversight } \\
\hline $\begin{array}{l}\text { 15. A CCP should be subject to } \\
\text { transparent and effective } \\
\text { regulation and oversight. In both } \\
\text { a domestic and an international } \\
\text { context, central banks and } \\
\text { securities regulators should co- } \\
\text { operate with each other and with } \\
\text { other relevant authorities. }\end{array}$ & $\begin{array}{l}\text { The role and responsibilities of relevant public authorities with } \\
\text { respect to clearing activities are clearly defined and } \\
\text { transparent. The CCP's supervision and oversight are risk- } \\
\text { based and thus are implemented on a prioritization basis. } \\
\text { They have been strengthened since the crisis, both at the BoE } \\
\text { and the FSA. Hiring and keeping the right expertise is } \\
\text { challenging. The Government intends to transfer regulation } \\
\text { and supervision of central counterparty clearing houses to the } \\
\text { BoE by end-2012. }\end{array}$ \\
\hline
\end{tabular}


Table 13. United Kingdom: Recommended Action Plan

\begin{tabular}{|c|c|}
\hline \multicolumn{2}{|r|}{ Actions to achieve observance } \\
\hline Reference recommendation & Actions to achieve observance \\
\hline $\begin{array}{l}\text { Recommendation } 5 \text { - } \\
\text { Financial Resources }\end{array}$ & $\begin{array}{l}\text { LCH should put in place other safe and reliable funding options, } \\
\text { which should include committed credit lines subject only to } \\
\text { presentment, and could also include other options like } \\
\text { mutualization of liquidity risk among the CCP's membership. } \\
\text { This would help it face extreme but plausible circumstances, } \\
\text { such as disruptions to its tri-party repo arrangements or } \\
\text { dislocations in the repo market. }\end{array}$ \\
\hline $\begin{array}{l}\text { Recommendation } 7 \text { - } \\
\text { Custody and Investment Risks }\end{array}$ & $\begin{array}{l}\text { LCH needs to confirm that the US custodian it currently employs, } \\
\text { and any future custodians it may use, conform to } \\
\text { Recommendation } 12 \text { of the RSSS (i.e., that they employ } \\
\text { accounting practices and safekeeping procedures that fully } \\
\text { protect customers' securities). }\end{array}$ \\
\hline $\begin{array}{l}\text { Recommendation } 9 \text { - } \\
\text { Money settlements }\end{array}$ & $\begin{array}{l}\text { LCH should find a way to reduce its settlement exposures to } \\
\text { PPS and commercial concentration banks. Settlement should be } \\
\text { in central bank money when possible. }\end{array}$ \\
\hline \multicolumn{2}{|r|}{ Additional actions } \\
\hline Reference recommendation & Additional actions \\
\hline $\begin{array}{l}\text { Recommendation } 3 \text { - } \\
\text { Measurement and Management } \\
\text { of Credit Exposures }\end{array}$ & $\begin{array}{l}\text { LCH should develop a routine capacity to recalculate exposures } \\
\text { intraday for the LIFFE market. }\end{array}$ \\
\hline $\begin{array}{l}\text { Recommendation } 4 \text { - } \\
\text { Margin Requirements }\end{array}$ & $\begin{array}{l}\text { For the LIFFE market, if prices are particularly volatile, then LCH } \\
\text { will make an intraday call based on the previous day's positions. } \\
\text { LCH should develop the routine capacity to do so using intraday } \\
\text { positions. }\end{array}$ \\
\hline $\begin{array}{l}\text { Recommendation } 8 \text { - } \\
\text { Operational risk }\end{array}$ & $\begin{array}{l}\text { LCH should consider making contingency testing compulsory for } \\
\text { the largest participants to ensure they are operationally reliable } \\
\text { and have in place tested contingency arrangements to deal with } \\
\text { an operational failure, affecting either their access to LCH or } \\
\text { LCH itself. } \\
\text { Such a core and global infrastructure should consider } \\
\text { implementing a second back-up site ( } 3 \text { sites architecture), } \\
\text { located outside the greater London area. }\end{array}$ \\
\hline $\begin{array}{l}\text { Recommendation } 13 \text { - } \\
\text { Governance }\end{array}$ & $\begin{array}{l}\text { LCH should publish information about its management structure, } \\
\text { and disclose detailed objectives to participants and the extent to } \\
\text { which they are met. }\end{array}$ \\
\hline
\end{tabular}




\section{Actions to achieve observance}

\begin{tabular}{|l|l|}
\hline Recommendation 14- & $\begin{array}{l}\text { Additional public information would be welcome, for example on } \\
\text { concentration banks and LCH's activity (statistics). } \\
\text { Transparency }\end{array}$ \\
$\begin{array}{l}\text { The assessors encourage LCH to publish a more detailed self- } \\
\text { assessment. }\end{array}$ \\
\hline Recommendation 15- & $\begin{array}{l}\text { In addition to their existing market intelligence meetings, the } \\
\text { FSA and the BoE may want to set up regular dedicated } \\
\text { meetings with individual LCH participants and partners (such as } \\
\text { exchanges, PPS, and concentration banks) to get their views on } \\
\text { the efficiency and robustness of the CCP, and assess their own } \\
\text { interaction with the system. }\end{array}$ \\
\hline
\end{tabular}

\section{E. Authorities' Response}

\section{The U.K. authorities welcome this assessment of the LCH.Clearnet Limited against the CPSS/IOSCO RCCPs.}

\section{The U.K.'s supervision and oversight of $\mathrm{LCH}$ has changed since the financial}

crisis. It is therefore reassuring that the IMF notes the strengthened supervision and oversight of LCH.

156. The assessment identifies recommended action which would improve observance with the RCCP and the U.K. authorities will consider and review all of the assessors' recommendations.

\section{Finally, the authorities wish to express their strong support of the FSAP} initiative and look forward to a continuing dialogue with the IMF and other global counterparts to seek to improve the stability and effective supervision of the global financial system. 